\title{
Overview of a Comprehensive Resource Database for the Assessment of Recoverable Hydrocarbons Produced by Carbon Dioxide Enhanced Oil Recovery
}

Chapter 16 of

Section C, Computer Programs

Book 7, Automated Data Processing and Computations

Techniques and Methods 7-C16

Version 1.1, June 2018 



\section{Overview of a Comprehensive Resource Database for the Assessment of Recoverable Hydrocarbons Produced by Carbon Dioxide Enhanced Oil Recovery}

By Marshall Carolus, Khosrow Biglarbigi, Peter D. Warwick, Emil D. Attanasi,

Philip A. Freeman, and Celeste D. Lohr

Chapter 16 of

Section C, Computer Programs

Book 7, Automated Data Processing and Computations

Techniques and Methods 7-C16

Version 1.1, June 2018

U.S. Department of the Interior

U.S. Geological Survey 


\title{
U.S. Department of the Interior \\ RYAN K. ZINKE, Secretary
}

\section{U.S. Geological Survey James F. Reilly II, Director}

\author{
U.S. Geological Survey, Reston, Virginia \\ First release: 2017 \\ Revised: June 2018 (ver 1.1)
}

\begin{abstract}
For more information on the USGS - the Federal source for science about the Earth, its natural and living resources, natural hazards, and the environment-visit https://www.usgs.gov or call 1-888-ASK-USGS.

For an overview of USGS information products, including maps, imagery, and publications, visit https://store.usgs.gov.
\end{abstract}

Any use of trade, firm, or product names is for descriptive purposes only and does not imply endorsement by the U.S. Government.

Although this information product, for the most part, is in the public domain, it also may contain copyrighted materials as noted in the text. Permission to reproduce copyrighted items must be secured from the copyright owner.

Suggested citation:

Carolus, M., Biglarbigi, K., Warwick, P.D., Attanasi, E.D., Freeman, P.A., and Lohr, C.D., 2018, Overview of a comprehensive resource database for the assessment of recoverable hydrocarbons produced by carbon dioxide enhanced oil recovery (ver 1.1, June 2018): U.S. Geological Survey Techniques and Methods, book 7, chap. C16, 31 p., https://doi.org/10.3133/tm7C16. 


\section{Contents}

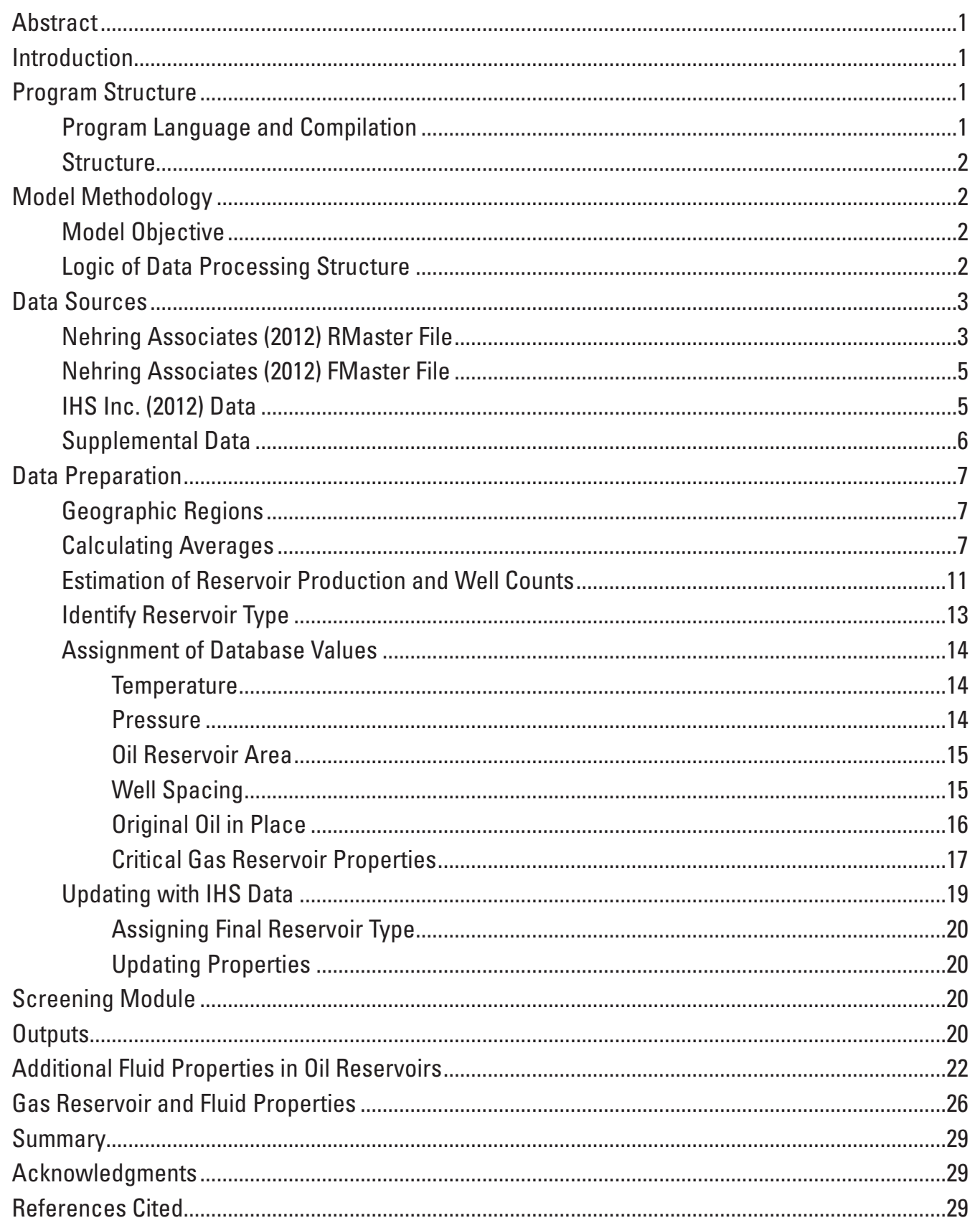




\section{Figures}

1. Flowchart showing the logic steps of the data processing algorithm that builds the Comprehensive Resource Database.

2. Flowchart showing the three data types and sources used in compiling the Comprehensive Resource Database.

3. Maps showing the petroleum regions and provinces of the conterminous United States and Alaska

4. Chart showing the steps taken to estimate missing reservoir production data and the number of active and producing wells .............................................................10

5. Flowchart showing the process for identifying reservoir type .......................................13

6. Flowchart showing the steps taken to estimate and calculate oil and gas property values

7. Flowchart showing the process steps for updating Nehring Associates (2012) production and well-count data with IHS Inc. (2012) field production and well-count data

\section{Tables}

1. Key petrophysical properties from the Nehring Associates (2012) database used in the Comprehensive Resource Database....

2. Calculated oil and gas reservoir properties in the Comprehensive Resource Database

3. Nehring Associates (2012) oil and gas reservoir identification, reservoir characteristics and properties, and production and reserves data through 2010

4. Nehring Associates (2012) field identification, field properties, production data,

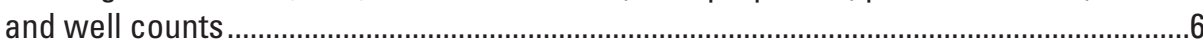

5. IHS Inc. (2012) field identification, production data, and well counts ...............................6

6. List of petroleum regions and provinces of onshore and State offshore areas in the conterminous United States and Alaska

7. Average reservoir properties calculated for the Comprehensive Resource Database

8. List of reservoir properties that are updated with IHS Inc. (2012) data after the final reservoir type assignment.

9. Screening criteria for miscible and immiscible flooding

10. Major output files generated in creation of the Comprehensive Resource Database 


\section{Conversion Factors}

\begin{tabular}{|c|c|c|}
\hline Multiply & By & To obtain \\
\hline \multicolumn{3}{|c|}{ Length } \\
\hline foot $(\mathrm{ft})$ & 0.3048 & meter $(\mathrm{m})$ \\
\hline kilometer $(\mathrm{km})$ & 0.6214 & mile (mi) \\
\hline \multicolumn{3}{|c|}{ Area } \\
\hline square inch $\left(\mathrm{in}^{2}\right)$ & 6.452 & square centimeter $\left(\mathrm{cm}^{2}\right)$ \\
\hline acre & 43,560 & square foot $\left(\mathrm{ft}^{2}\right)$ \\
\hline \multicolumn{3}{|c|}{ Volume } \\
\hline barrel (bbl) of petroleum & 42 & gallon (gal) \\
\hline barrel (bbl) of petroleum & 0.1590 & cubic meter $\left(\mathrm{m}^{3}\right)$ \\
\hline thousand barrels (Mbbl) of petroleum & 1,000 & barrel (bbl) of petroleum \\
\hline million barrels (MMbbl) of petroleum & $1,000,000$ & barrel (bbl) of petroleum \\
\hline cubic foot $\left(\mathrm{ft}^{3}\right)$ & 0.02832 & cubic meter $\left(\mathrm{m}^{3}\right)$ \\
\hline thousand cubic feet (Mcf) & 28.32 & cubic meter $\left(\mathrm{m}^{3}\right)$ \\
\hline million cubic feet (MMcf) & 2,832 & cubic meter $\left(\mathrm{m}^{3}\right)$ \\
\hline billion cubic feet (Bcf) & $28,316,847$ & cubic meter $\left(\mathrm{m}^{3}\right)$ \\
\hline \multicolumn{3}{|c|}{ Mass } \\
\hline pound, avoirdupois (lb) & 0.4536 & kilogram $(\mathrm{kg})$ \\
\hline \multicolumn{3}{|c|}{ Pressure } \\
\hline $\begin{array}{l}\text { pound-force per square inch } \\
\left(\mathrm{lbf} / \mathrm{in}^{2} \text { or psi) measured in ambient }\right. \\
\text { atmospheric pressure }\end{array}$ & 6.895 & kilopascal $(\mathrm{kPa})$ \\
\hline $\begin{array}{l}\text { pound-force per square inch }\left(\mathrm{lbf} / \mathrm{in}^{2}\right. \\
\text { or psia) absolute measured in a } \\
\text { vacuum }\end{array}$ & 6.895 & kilopascal (kPa) \\
\hline \multicolumn{3}{|c|}{ Pressure gradient } \\
\hline $\begin{array}{l}\text { pound-force per square inch per foot } \\
\left(\mathrm{lbf} / \mathrm{in}^{2} / \mathrm{ft} \text { or } \mathrm{psi} / \mathrm{ft}\right)\end{array}$ & 22.62 & kilopascal per meter $(\mathrm{kPa} / \mathrm{m})$ \\
\hline \multicolumn{3}{|c|}{ Geothermal gradient } \\
\hline degrees Fahrenheit per foot $\left({ }^{\circ} \mathrm{F} / \mathrm{ft}\right)$ & 1.82 & degrees Celsius per meter $\left({ }^{\circ} \mathrm{C} / \mathrm{m}\right)$ \\
\hline \multicolumn{3}{|c|}{ Permeability } \\
\hline millidarcy $(\mathrm{mD})$ & $9.869 \times 10^{-16}$ & square meter $\left(\mathrm{m}^{2}\right)$ \\
\hline \multicolumn{3}{|c|}{ Viscosity } \\
\hline centipoise $(\mathrm{cP})$ & 1 & millipascal second $(\mathrm{mPa} \cdot \mathrm{s})$ \\
\hline \multicolumn{3}{|c|}{ Energy } \\
\hline British thermal unit (Btu) & 1 & $1,055.05585262$ joules $(\mathrm{J})$ \\
\hline
\end{tabular}

Temperature in degrees Celsius $\left({ }^{\circ} \mathrm{C}\right)$ may be converted to degrees Fahrenheit $\left({ }^{\circ} \mathrm{F}\right)$ as follows:

$$
{ }^{\circ} \mathrm{F}=\left(1.8 x^{\circ} \mathrm{C}\right)+32
$$

Temperature in degrees Fahrenheit $\left({ }^{\circ} \mathrm{F}\right)$ may be converted to degrees Celsius $\left({ }^{\circ} \mathrm{C}\right)$ as follows:

$$
{ }^{\circ} \mathrm{C}=\left({ }^{\circ} \mathrm{F}-32\right) / 1.8
$$

Temperature in degrees Fahrenheit $\left({ }^{\circ} \mathrm{F}\right)$ may be converted to degrees Rankine (oR) as follows:

$$
{ }^{\circ} \mathrm{R}={ }^{\circ} \mathrm{F}+460
$$

1 barrel of oil equivalent $(\mathrm{BOE})=1$ barrel of crude oil (42 gallons)

$$
\begin{aligned}
& =6,000 \text { cubic feet of natural gas } \\
& =1.5 \text { barrels of natural gas liquids }
\end{aligned}
$$




\section{Abbreviations}

$a$

A

ACPROD

API

Area

Area00IP

B

bbl

Bcf

$B_{\text {C02 }}$

$B G C$

$B G I$

$B O C$

BOE

BOI

Btu

$\mathrm{CO}_{2}$

cP

CRD

crespro

cumprod

$\operatorname{Dary}(i, 16)$

$\operatorname{Dary}(i, 17)$

dist

dist_(a,res)

EIA

EIA ID

EOR

$E R$ reservoir production proration factor one, two, or three

coefficient value determined by the value of the solution gas-oil ratio (Beggs and Robinson, 1975)

producing area, in acres

American Petroleum Institute gravity of oil, in degrees API ( $\left.{ }^{\circ} \mathrm{API}\right)$

reservoir area, in acres

calculated recoverable original oil in place, in stock tank barrels (STB) or thousands of stock tank barrels (MSTB)

is an exponent determined by the value of the solution gas-oil ratio (Beggs and Robinson, 1975)

barrel

billions of cubic feet

$\mathrm{CO}_{2}$ formation volume factor, in decimal format

current gas formation volume factor, in decimal format

initial gas formation volume factor, in decimal format

current oil formation volume factor, in decimal format

barrel of oil equivalent

initial oil formation volume factor, in decimal format

British thermal unit

carbon dioxide

centipoise

Comprehensive Resource Database

NRG cumulative production of the reservoir (2008-2010), in thousands of barrels (Mbbl) or billions of cubic feet (Bcf)

cumulative oil production, in thousands of barrels (Mbbl); or the cumulative gas production, in billions of cubic feet (Bcf)

depth of play, in feet (ft) in year (i), 16th numerical position in Fortran computer code

temperature of play, in degrees Fahrenheit $\left({ }^{\circ} \mathrm{F}\right)$ in year $(i), 17$ th numerical position in Fortran computer code

fraction of proration factor " $a$ " for the reservoir

reservoir distribution factor

U.S. Energy Information Administration

U.S. Energy Information Administration identification

enhanced oil recovery

recovery factor after waterflood, in decimal format 
EUR

$E V_{1}$

$E V_{2}$

$\exp$

F

fact_one(res)

fact_two(res)

fact_three(res)

fdata(ifld,iyr)

fldwell(ifld, iyr)

FMaster

$\mathrm{ft}$

GIPVOL

GOR

$\mathrm{H}_{2} \mathrm{~S}$

i

ifld

IHS

Ihsprod

iyr

k

$K R_{\text {gas }}$

$K R_{N G L}$

$K R_{\text {oil }}$

Mbbl

Mcf

$\mathrm{mD}$

MMbbl

MMcf

MMP estimated ultimate recovery, in standard cubic feet (Scf) or millions of cubic feet (MMcf)

pseudo-volumetric sweep efficiency, in decimal format

pseudo-volumetric sweep efficiency, in decimal format

exponent to the base e (the base of natural logarithms approximately equal to 2.71828 )

coefficient for the initial oil formation volume factor equation

is proration factor one

is proration factor two

is proration factor three

annual field production of oil, gas, or natural gas liquids (NGL) in year analyzed (iyr)

annual number of wells in the field in year analyzed (iyr)

Nehring Associates (2012) (NRG) field reservoir data

feet

original gas-in-place volume per unit area, in standard cubic feet per acre (Scf/acre)

gas-oil ratio

hydrogen sulfide

year

field that is matched to the reservoir

IHS Inc. (2012)

IHS Inc. (2012) (IHS) annual oil or gas production from the field, in thousands of barrels (Mbbl) or millions of cubic feet (MMcf)

year analyzed

play being analyzed

Nehring Associates (2012) (NRG) known gas recovery (cumulative production plus reported reserves), in millions of cubic feet (MMcf)

Nehring Associates (2012) (NRG) known natural gas liquids (NGL) recovery (cumulative production plus reported reserves), in thousands of barrels (Mbbl)

Nehring Associates (2012) (NRG) known oil recovery (cumulative production plus reported reserves), in thousands of barrels (Mbbl)

thousands of barrels

thousands of cubic feet

millidarcy

millions of barrels

millions of cubic feet

minimum miscibility pressure 


\begin{tabular}{|c|c|}
\hline MSTB & thousands of stock tank barrels \\
\hline $\mathrm{N}_{2}$ & nitrogen \\
\hline NETL & National Energy Technology Laboratory \\
\hline NetPay & net reservoir thickness, in feet (ft) \\
\hline NGL & natural gas liquids \\
\hline NOGA & USGS National Oil and Gas Assessment \\
\hline NPC & National Petroleum Council \\
\hline nres & number of reservoirs in the field \\
\hline NRG & Nehring Associates (2012) database \\
\hline NRG ID & Nehring Associates (2012) database identification number \\
\hline num_thick & number of non-zero values in the play or province \\
\hline OGIP & $\begin{array}{l}\text { original gas in place, in standard cubic feet (Scf) or billions of cubic } \\
\text { feet (Bcf) }\end{array}$ \\
\hline $001 P$ & $\begin{array}{l}\text { original oil in place, in stock tank barrels (STB) or thousands of stock tank } \\
\text { barrels (MSTB) }\end{array}$ \\
\hline OrgArea(i) & calculated reservoir area, in acres in year (i) \\
\hline playthick & $\begin{array}{l}\text { non-zero average thickness of the reservoir in the play or province, in } \\
\text { feet (ft) }\end{array}$ \\
\hline Ply_PresGr & $\begin{array}{l}\text { average pressure gradient of play, in pound-force per square inch per } \\
\text { foot (psi/ft) }\end{array}$ \\
\hline Ply_TempGr & average temperature gradient of play, in degrees Fahrenheit per foot $\left({ }^{\circ} \mathrm{F} / \mathrm{ft}\right)$ \\
\hline Por & reservoir rock porosity, in decimal format \\
\hline PRESC & current reservoir pressure, in pound-force per square inch absolute (psia) \\
\hline PresCal & $\begin{array}{l}\text { calculated initial reservoir pressure, in pound-force per square inch } \\
\text { absolute (psia) }\end{array}$ \\
\hline PRESIN & initial reservoir pressure, in pound-force per square inch absolute (psia) \\
\hline psi & pound-force per square inch \\
\hline psia & pound-force per square inch absolute \\
\hline RECY & gas reservoir recovery factor, in decimal format \\
\hline res & reservoir analyzed \\
\hline respro & $\begin{array}{l}\text { annual reservoir oil, gas, or natural gas liquid (NGL) production, in } \\
\text { thousands of barrels (Mbbl) or millions of cubic feet (MMcf) }\end{array}$ \\
\hline respro(res,iyr) & $\begin{array}{l}\text { annual reservoir production of oil, gas, or natural gas liquids (NGL) in year } \\
\text { analyzed (iyr) }\end{array}$ \\
\hline resprod(res,iyr) & $\begin{array}{l}\text { annual production of oil, gas, or natural gas liquid (NGL) converted to } \\
\text { barrels of oil equivalent (BOE) in year analyzed (iyr) }\end{array}$ \\
\hline reswell(res,iyr) & annual number of wells in the reservoir in year analyzed (iyr) \\
\hline RMaster & Nehring Associates (2012) (NRG) reservoir properties and production data \\
\hline
\end{tabular}


RS

Scf

Scf/acre

SGC

SGG

SGI

SGO

SOC

SOI

SORW

STB

SWC

SWI

thick

Tres

Tres

Tres

U.S.

USGS

$\mathrm{VCO}_{2}$

VDP

VWAT

WATIN

WLSPC

WOR

$X$

$Y g$

$Z_{c}$

$Z_{\text {CO2 }}$

$Z$ factor

$Z_{i}$

$\mu$

$\mu \_D E A D$

$\mu_{-} L I V E$ solution gas-oil ratio, in standard cubic feet per stock tank barrel (Scf/STB)

standard cubic foot at standard conditions (14.73 pound-force per square inch [psi] and 60 degrees Fahrenheit [ $\left.\left.{ }^{\circ} \mathrm{F}\right]\right)$

standard cubic feet per acre

current gas saturation, in decimal format

specific gravity of the gas, air=1

initial gas saturation, in decimal format

specific gravity of oil

current oil saturation, in decimal format

initial oil saturation, in decimal format

residual oil saturation after waterflood, in decimal format

stock tank barrel (volume of treated oil stored in stock tanks at surface conditions; the size of a stock tank barrel is the same as the size of a regular barrel [bbl])

current water saturation, in decimal format

initial water saturation, in decimal format

non-zero thickness of the reservoir in the play or province

reservoir temperature, in degrees Fahrenheit $\left({ }^{\circ} \mathrm{F}\right)$

current reservoir temperature, in degrees Fahrenheit $\left({ }^{\circ} \mathrm{F}\right)$

initial reservoir temperature, in degrees Fahrenheit $\left({ }^{\circ} \mathrm{F}\right)$

United States

U.S. Geological Survey

carbon dioxide viscosity, in centipoise (cP)

pseudo-Dykstra-Parsons coefficient

water viscosity, in centipoise (cP)

reservoir water influx (volume)

well spacing

water-oil ratio

coefficient for the Beggs and Robinson (1975) correlation equation

coefficient for the solution gas-oil ratio equation

current gas compressibility factor, dimensionless

$\mathrm{CO}_{2}$ compressibility factor, $\mathrm{CO}_{2}$ dimensionless Z-factor

compressibility of gas

initial gas compressibility factor

oil viscosity, in centipoise (cP)

dead oil viscosity (no dissolved gas), in centipoise (cP)

live oil viscosity (with dissolved gas), in centipoise (cP) 



\title{
Overview of a Comprehensive Resource Database for the Assessment of Recoverable Hydrocarbons Produced by Carbon Dioxide Enhanced Oil Recovery
}

\author{
By Marshall Carolus, ${ }^{1}$ Khosrow Biglarbigi, ${ }^{1}$ Peter D. Warwick, ${ }^{2}$ Emil D. Attanasi, ${ }^{2}$ Philip A. Freeman, ${ }^{2}$ and \\ Celeste D. Lohr
}

\section{Abstract}

A database called the "Comprehensive Resource Database" (CRD) was prepared to support U.S. Geological Survey (USGS) assessments of technically recoverable hydrocarbons that might result from the injection of miscible or immiscible carbon dioxide $\left(\mathrm{CO}_{2}\right)$ for enhanced oil recovery (EOR). The CRD was designed by INTEK Inc., a consulting company under contract to the USGS. The CRD contains data on the location, key petrophysical properties, production, and well counts (number of wells) for the major oil and gas reservoirs in onshore areas and State waters of the conterminous United States and Alaska. The CRD includes proprietary data on petrophysical properties of fields and reservoirs from the "Significant Oil and Gas Fields of the United States Database," prepared by Nehring Associates in 2012, and proprietary production and drilling data from the "Petroleum Information Data Model Relational U.S. Well Data," prepared by IHS Inc. in 2012. This report describes the CRD and the computer algorithms used to (1) estimate missing reservoir property values in the Nehring Associates (2012) database, and to (2) generate values of additional properties used to characterize reservoirs suitable for miscible or immiscible $\mathrm{CO}_{2}$ flooding for EOR. Because of the proprietary nature of the data and contractual obligations, the CRD and actual data from Nehring Associates (2012) and IHS Inc. (2012) cannot be presented in this report.

\section{Introduction}

The Comprehensive Resource Database (CRD) was developed to support U.S. Geological Survey (USGS) assessments of technically recoverable hydrocarbons that could be potentially recovered from qualifying reservoirs through enhanced oil recovery (EOR) using carbon dioxide $\left(\mathrm{CO}_{2}\right)$. The

${ }^{1}$ INTEK Inc., under contract to the U.S. Geological Survey.

${ }^{2}$ U.S. Geological Survey.
CRD was designed by INTEK Inc., a petroleum engineering consulting company under contract to the USGS (contract G13PC00006). The CRD contains data relating to the location, key petrophysical properties, production, and the "well count" (number of wells) for the major oil and gas reservoirs in the onshore and State waters areas of the conterminous United States and Alaska. The data within the CRD are proprietary because they include (1) field and reservoir properties data from the proprietary sources "Significant Oil and Gas Fields of the United States Database" (also referred to as "NRG" or "NRG database" in this report) prepared by Nehring Associates in 2012, and (2) proprietary production and drilling data from "Petroleum Information Data Model Relational U.S. Well Data" (also referred to as "IHS" in this report) prepared by IHS Inc. in 2012.

The following sections provide a description of (1) the CRD computer program and its methodology, (2) a list of the key data sources used in its development, (3) a description of the steps and routines used to prepare the CRD, (4) the screening criteria for miscible or immiscible $\mathrm{CO}_{2}$ flooding applied to the $\mathrm{CRD}$, and (5) the database outputs. The resulting CRD contains a deterministic representation of reservoir properties that will be used in a probabilistic methodology that the USGS is developing to estimate technically recoverable oil resulting from the application of the $\mathrm{CO}_{2}$-EOR process. A description of the equations used in the calculations, a list of the input and output reservoir property data, the computer code, and the CRD are on file at the USGS Eastern Energy Resources Science Center located in Reston, Virginia.

\section{Program Structure}

\section{Program Language and Compilation}

The computer code that generated the CRD was developed using Lahey Fortran 90® (software owned by INTEK) and the Lahey/Fujitsu Fortran Professional v7.3® (owned by USGS). The model was coded using Fortran 77 standards and compiled using the LF95 Lahey/Fujitsu optimized compiler. 


\section{Structure}

The computer code that generated the CRD contains files and executables in three main directories. The directories are Input, Code, and Output. The data files used to prepare the CRD are contained in the Input directory. The executable and source code for the program are contained in the Code directory. The processed data files, created by the CRD computer code, are contained in the Output directory. Descriptions of the input and output files are provided in the respective sections of this report. The three directories are not part of this report, and will not be available to the public because of their proprietary nature.

\section{Model Methodology}

\section{Model Objective}

The computer code that generated the CRD uses a series of Fortran $90 \AA$ routines, based upon petroleum engineering principles, to ensure the completeness and internal consistency of the Nehring Associates (2012) data contained within the resource database. As discussed in this report, the routines check the values contained in the Nehring Associates (2012) database, modify those which are inconsistent with production or other reservoir properties, and estimate the missing values with average values calculated from reservoirs of the same play or province. The reservoirs were organized by the geologic plays and provinces identified in the USGS 1995 National Oil and Gas Assessment (NOGA) (Beeman and others, 1996). In addition, the routines determine the classification of the reservoir (as oil or gas) and incorporate reservoir production and drilling data from IHS Inc. (2012). This methodology has previously been applied to the "Comprehensive Oil and Gas Analysis Model" prepared by the U.S. Department of Energy National Energy Technology Laboratory (2004), and to the "Onshore Lower 48 Oil and Gas Supply Submodule" (INTEK Inc. and Resource Consultants Inc., 2006) within the National Energy Modeling System at the U.S. Energy Information Administration.

\section{Logic of Data Processing Structure}

The computer code that generated the CRD has a modular structure with seven major components (fig. 1). The steps described below utilize the various data elements listed in tables 1 through 5 . These seven principal components of the processing logic include:

1. Read NRG data and supplemental data: opens and reads the input files used in the module.

2. Calculate average properties for oil and gas reservoirs: uses the Nehring Associates (2012) data along with supplemental data (described below) to calculate the average values for key petrophysical properties for each play, province, and region. The key properties are listed in table 1 .

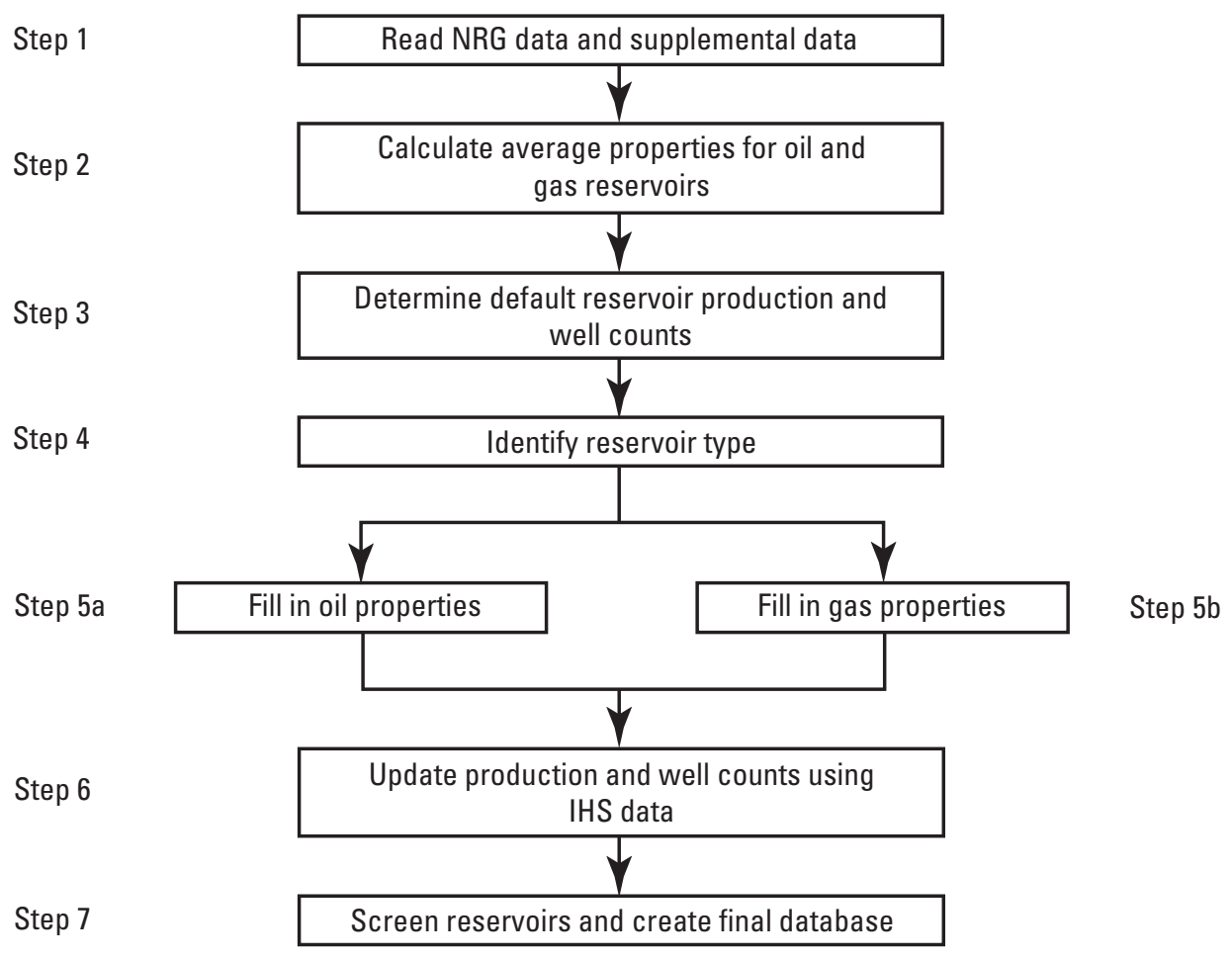

Figure 1. Flowchart showing the logic steps of the data processing algorithm that builds the Comprehensive Resource Database (CRD). Abbreviations: NRG, Nehring Associates (2012) database; IHS, IHS Inc. (2012). 
Table 1. Key petrophysical properties from the Nehring Associates (2012) database used in the Comprehensive Resource Database (CRD).

[The computer code that generated the CRD calculates the arithmetic average values at the play, province, region, or Nation levels, as well as the maximum and minimum values for the properties. Abbreviations: API, American Petroleum Institute; $\mathrm{CO}_{2}$, carbon dioxide; $\mathrm{H}_{2} \mathrm{~S}$, hydrogen sulfide; $\mathrm{N}_{2}$, nitrogen]

\begin{tabular}{lll}
\hline \multicolumn{1}{c}{ Oil and gas reservoirs } & \multicolumn{1}{c}{ Oil reservoirs } & \multicolumn{1}{c}{ Gas reservoirs } \\
\hline Net pay (thickness) & Initial oil saturation & Initial gas saturation \\
Depth & Initial water saturation & Initial water saturation \\
Temperature gradient & Initial formation volume factor & $\mathrm{CO}_{2}$ concentration \\
Pressure gradient & API gravity of oil & $\mathrm{N}_{2}$ concentration \\
Porosity & Specific gravity of the gas & $\mathrm{H}_{2} \mathrm{~S}$ concentration \\
Permeability & Well spacing & Specific gravity of the gas \\
& Sulfur content & Heat content \\
& & Sulfur content \\
\hline
\end{tabular}

3. Determine default reservoir production and well counts: the Nehring Associates (2012) database is used for annual oil, gas, and natural gas liquids (NGL) production data and well counts for each reservoir.

4. Identify reservoir type: for purposes of classifying reservoirs as oil or gas and noting that only oil reservoirs will be candidates for $\mathrm{CO}_{2}$ enhanced oil recovery (EOR), an oil reservoir was defined as having less than 10,000 standard cubic feet (Scf) of natural gas per stock tank barrel (STB) of oil. This classification conforms to the demonstrated $\mathrm{CO}_{2}$-EOR projects listed in Kootungal $(2012,2014)$ and is used by some regulatory agencies to determine the primary product of hydrocarbon reservoirs (British Columbia Oil and Gas Commission, 2014). This value is lower than the 20,000 standard cubic feet per barrel (Scf/bbl) limit used in USGS assessments of undiscovered oil and gas resources (Klett and others, 2005).

5. Fill in oil and gas properties: computes the oil and gas properties in the database (shown as steps $5 \mathrm{a}$ and $5 \mathrm{~b}$ in fig. 1). In addition, an accompanying "shadow" database is created that specifies the data source for each estimated property. Table 2 displays the calculated oil and gas properties.

6. Update production and well counts using IHS data: updates the reservoir production, and well counts using IHS Inc. (2012) data.

7. Screen reservoirs and create final database: creates the final reservoir database by applying screening criteria (described below) to determine the candidates for miscible and immiscible $\mathrm{CO}_{2}$-EOR.

\section{Data Sources}

The database is assembled from the following three data types and sources: (1) reservoir and field production data and properties from the Nehring Associates (2012) database, (2) field-level production and well-count data from IHS Inc. (2012), and (3) supplemental data from several different sources (fig. 2). The routines and equations discussed below are used to ensure that the data from these sources are complete and internally consistent. This section describes the data sources.

Nehring Associates (2012) provides reservoir (RMaster) and field (FMaster) production data, well counts, and key petrophysical properties for the major oil and gas fields and reservoirs in the United States. Production and well-count data are current through 2010 in the database from Nehring Associates (2012). These two Nehring Associates (2012) files (RMaster, FMaster) are used in the assembly of the reservoir data in the CRD. All data in the CRD from Nehring Associates (2012) are provided in English units unless otherwise noted.

\section{Nehring Associates (2012) RMaster File}

The Nehring Associates (2012) RMaster file contains data for approximately 26,000 oil and gas reservoirs in the United States. There are three basic types of reservoir data in the NRG RMaster file, including: (1) reservoir identification information, (2) reservoir characteristics and properties, and (3) reservoir production and reserves through 2010. The computer code that generates the CRD uses the input values from the NRG RMaster file for these 3 types of reservoir data shown in table 3 . 
Table 2. Calculated oil and gas reservoir properties in the Comprehensive Resource Database (CRD).

[The averaged property values in the CRD are indicated by footnote 1. Abbreviations: API, American Petroleum Institute; $\mathrm{CO}_{2}$, carbon dioxide; $\mathrm{H}_{2} \mathrm{~S}$, hydrogen sulfide; $\mathrm{N}_{2}$, nitrogen; NGL, natural gas liquids; $\mathrm{Z}$ factor, compressibility of gas]

\begin{tabular}{|c|c|}
\hline Oil properties & Gas properties \\
\hline${ }^{1}$ Net pay (thickness) & ${ }^{1}$ Net pay (thickness) \\
\hline${ }^{1}$ Depth & ${ }^{1}$ Depth \\
\hline${ }^{1}$ Temperature gradient & ${ }^{1}$ Temperature gradient \\
\hline${ }^{1}$ Pressure gradient & ${ }^{1}$ Pressure gradient \\
\hline${ }^{1}$ Porosity & ${ }^{1}$ Porosity \\
\hline${ }^{1}$ Permeability & ${ }^{1}$ Permeability \\
\hline${ }^{1}$ Initial oil saturation & ${ }^{1}$ Initial gas saturation \\
\hline${ }^{1}$ Initial water saturation & ${ }^{1}$ Initial water saturation \\
\hline${ }^{1}$ Initial formation volume factor & ${ }^{1} \mathrm{CO}_{2}$ concentration \\
\hline${ }^{1}$ API gravity of oil & ${ }^{1} \mathrm{~N}_{2}$ concentration \\
\hline${ }^{1}$ Specific gravity of the gas & ${ }^{1} \mathrm{H}_{2} \mathrm{~S}$ concentration \\
\hline${ }^{1}$ Well spacing & ${ }^{1}$ Specific gravity of the gas \\
\hline Reservoir area & ${ }^{1}$ Heat content \\
\hline Active wells & ${ }^{1}$ Sulfur content \\
\hline${ }^{2}$ Original oil in place & Initial gas formation volume factor \\
\hline Recovery factor & Lithology type \\
\hline Current pressure & Well spacing \\
\hline Current formation volume factor & Producing area \\
\hline Current oil saturation & Gas compressibility \\
\hline Current water saturation & Gas-in-place volume \\
\hline Current gas saturation & Recovery factor \\
\hline Gas-to-oil ratio & Original gas in place \\
\hline Swept zone oil saturation & Current gas formation volume factor \\
\hline Viscosity & Current temperature \\
\hline Pseudo Dykstra-Parsons coefficient & Current oil saturation \\
\hline Size class & Current water saturation \\
\hline \multirow[t]{7}{*}{ Lithology } & Current gas saturation \\
\hline & Current $\mathrm{Z}$ factor \\
\hline & Water influx \\
\hline & NGL-to-gas ratio \\
\hline & Condensate-to-gas ratio \\
\hline & Viscosity \\
\hline & Size class \\
\hline
\end{tabular}

${ }^{1}$ Averaged property values in the CRD.

${ }^{2}$ Adjusted if recovery factor is greater than 35 percent. Adjusted volumetrics are checked against the play range and unpublished U.S. Geological Survey data. 


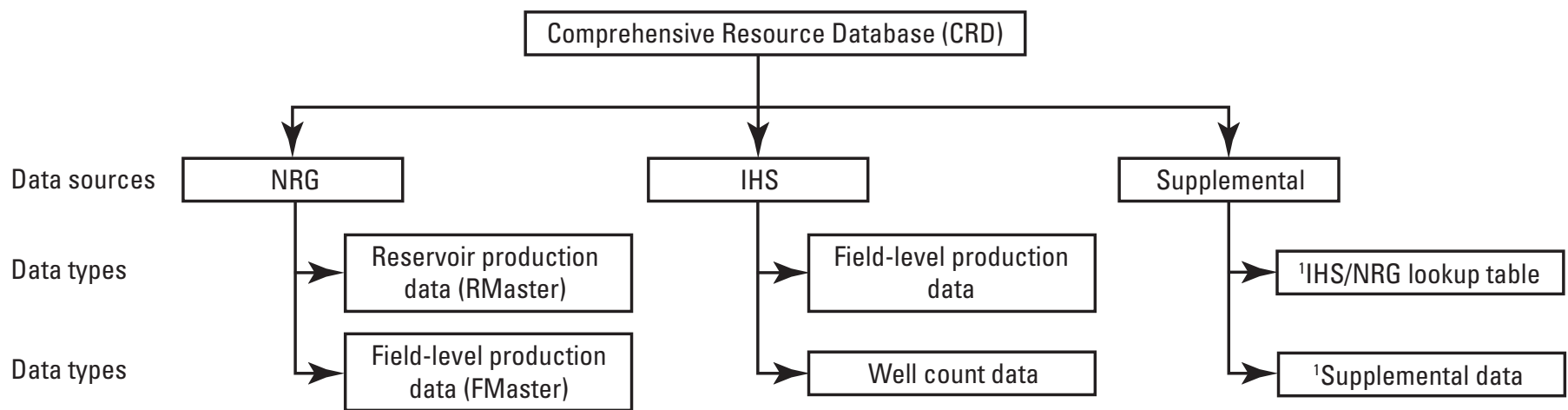

Figure 2. Flowchart showing the three data types and sources used in compiling the Comprehensive Resource Database (CRD). 'Described in report under Supplemental data. Abbreviations: IHS, IHS Inc. (2012); NRG, Nehring Associates (2012) database.

Table 3. Nehring Associates (2012) oil and gas reservoir identification, reservoir characteristics and properties, and production and reserves data through 2010 (all in the Nehring Associates (2012) RMaster file).

[Abbreviations: API, American Petroleum Institute; BOE, barrels of oil equivalent; Btu, British thermal units; EIA ID, U.S. Energy Information Administration identification number; NGL, natural gas liquids; NRG, Nehring Associates (2012) database; NRG ID, Nehring Associates (2012) database identification number; U.S., United States]

\begin{tabular}{|c|c|c|}
\hline Reservoir identification & Reservoir characteristics and properties & $\begin{array}{c}\text { Reservoir production and reserves data } \\
\text { through } 2010\end{array}$ \\
\hline $\begin{array}{l}\text { NRG ID } \\
\text { Field and reservoir names } \\
\text { State name } \\
\text { County name } \\
\text { Province name } \\
\text { NRG play number } \\
\text { U.S. play number } \\
\text { EIA ID } \\
\text { State code } \\
\text { County code } \\
\text { Province code }\end{array}$ & $\begin{array}{l}\text { Depth to top } \\
\text { Well spacing } \\
\text { Thickness } \\
\text { Permeability } \\
\text { Oil viscosity } \\
\text { Initial oil saturation } \\
\text { Initial gas saturation } \\
\text { Initial water saturation } \\
\text { Pressure } \\
\text { Lithology } \\
\text { Gas impurities } \\
\text { Oil formation volume factor } \\
\text { Reservoir area } \\
\text { Number of spacing units } \\
\text { Porosity } \\
\text { API gravity of oil } \\
\text { Specific gravity of the gas } \\
\text { Temperature } \\
\text { Gas Btu } \\
\text { Recovery factor } \\
\text { Age rank }\end{array}$ & $\begin{array}{l}\text { Oil, gas, and NGL } \\
\text { - Annual production (1991-2010) } \\
\text { - Known recovery (1991-2010) } \\
\text { - Cumulative production } \\
\text { - Proved reserves } \\
\text { BOE } \\
\text { - Known recovery (1991-2010) } \\
\text { - Cumulative production } \\
\text { - Proved reserves }\end{array}$ \\
\hline
\end{tabular}

\section{Nehring Associates (2012) FMaster File}

The Nehring Associates (2012) FMaster file contains data on approximately 17,000 oil and gas fields in the United States. There are four categories of field data in the NRG FMaster file, including: (1) field identification, (2) field properties, (3) production data through 2010, and (4) well counts (number of wells). The computer code that generates the CRD uses the input values from the NRG FMaster file for these 4 categories of field data shown in table 4 .

\section{IHS Inc. (2012) Data}

The IHS Inc. (2012) ("IHS") data contains well identification, production, and field information. All data from IHS are provided in English units unless otherwise noted. The USGS summed the IHS data to the field level and matched them with the corresponding NRG database fields. The summation process involved creating a file based on IHS data that contains the well counts, well type, and production data matched to the fields in the NRG database. The resulting 
Table 4. Nehring Associates (2012) field identification, field properties, production data, and well counts (all in the Nehring Associates (2012) FMaster file).

[Abbreviations: BOE, barrels of oil equivalent; EIA, U.S. Energy Information Administration; NGL, natural gas liquids; NRG ID, Nehring Associates (2012) database identification number]

\begin{tabular}{llll}
\hline \multicolumn{1}{c}{ Field identification } & \multicolumn{1}{c}{ Field properties } & Production data through 2010 & Well counts \\
\hline NRG ID & Field area & Oil, gas, and NGL & Active wells \\
Field name & Original oil in place & - Annual production & Producing wells \\
State name & Current oil recovery factor & - Known recovery & \\
County name & & - Cumulative production & \\
Province name & & - Proved reserves \\
EIA ID & & BOE \\
& & - Known recovery \\
& & - Cumulative production \\
\hline
\end{tabular}

Table 5. IHS Inc. (2012) field identification, production data, and well counts.

[Abbreviations: NRG ID, Nehring Associates (2012) database identification number]

\begin{tabular}{lll}
\hline \multicolumn{1}{c}{ Field identification } & \multicolumn{1}{c}{ Production data } & Well counts \\
\hline NRG ID & Annual production (2000-2012) & Annual number of wells (2000-2012) \\
Field name & - Oil & - Producing oil wells \\
State abbreviation & - Condensate & - Producing gas wells \\
County number & - Gas & - Injection wells \\
County name & - Casinghead gas & - New oil wells \\
Formation number & - Water produced & - New gas wells \\
Formation name & - Water injected & - New injection wells \\
& & \\
& Cumulative production & Cumulative number of wells \\
& - Oil & - Producing oil wells \\
& - Condensate & - Producing gas wells \\
& - Gas & - Injection wells \\
& - Casinghead gas & \\
\hline
\end{tabular}

IHS file contains the matched NRG identification number (NRG ID), annual production for 2000 to 2012, cumulative production, and annual and cumulative well counts (number of wells), as shown in table 5. The field production and well counts prior to the year 2000 were added as cumulative totals. The computer code uses the IHS data to extend the NRG production and well data to the most recent years (2010-2012).

The computer code that generates the CRD starts by matching the NRG cross reference to IHS data for each NRG ID. The program then finds the corresponding IHS data field and gathers all the well information by first assembling all the producing leases and wells (called "entities" in IHS) for the given IHS field. Once the program has all the entities, it loops through each entity by first counting all the oil, gas, and injection wells by summing the totals from year to year, then calculating the new well totals as positive values between years, and finally calculating the cumulative wells by adding all the new well totals together. After the well counts have been summed, the program calculates the production totals for oil, condensate, gas, casinghead gas, water produced, and water injected by looping through the monthly production table and summing all the monthly data to obtain yearly totals. The IHS fields "well counts" and "production data" are retrieved from the IHS data and then related to the associated NRG field in the cross reference. The program will also categorize these totals according to the U.S. State (determines State totals). Totals are converted from barrels (bbl) and thousands of cubic feet (Mcf) of gas to millions of barrels (MMbbl) and millions of cubic feet (MMcf) and then written to a formatted text file.

\section{Supplemental Data}

Some additional sources of information not contained in the Nehring Associates (2012) ("NRG") database and IHS Inc. (2012) ("IHS") data were required to help prepare the CRD. The following supplemental data were used in building the CRD: 
- IHS/NRG lookup table - Provides a cross reference between fields in the IHS data and NRG database. The version available to USGS was developed by Nehring Associates (2008).

- Active EOR projects - Projects tracked by the "Oil and Gas Journal" that is published semiannually as a special survey report. The reports used in the CRD are by Koottungal $(2012,2014)$, which list most active projects that are using either $\mathrm{CO}_{2}$, chemical, or thermal EOR processes. The EOR fields described by Koottungal $(2012,2014)$ were matched to a NRG ID. The CRD identifies these reservoirs as currently undergoing EOR.

- Water-oil ratios by State-Provided from the Argonne National Laboratory study by Clark and Veil (2009). The study reports hydrocarbon-specific wateroil ratios (WOR) for 15 States. For the remainder of States, the produced oil and water was used to calculate the WOR.

- State level oil and gas production-Provided by the U.S. Energy Information Administration (2013a, b). The petroleum online database provides annual data estimates on a continuing updated basis. These data are used to update reservoir totals in U.S. States where IHS does not provide current data.

- Default lithologies - Based on the dominant lithology of each USGS play reported in the USGS National assessment of the United States oil and gas resources by Gautier and others (1995) and are applied to the reservoirs for which the lithology in the NRG database is not provided.

- Unpublished USGS data-Reservoir type (conventional or continuous), temperature, pressure, and formation volume factor data are included in the CRD model. Reservoirs (accumulations) were designated as either conventional or continuous based on previous USGS assessment evaluations. Klett and others (2005) defines conventional reservoirs as having a discrete accumulation commonly bounded by a down-dip water contact and significantly affected by the buoyancy of petroleum in water; continuous accumulations are those that are pervasive throughout a large area, not significantly affected by hydrodynamic influences, and lack welldefined down-dip water contacts. The temperature, pressure, and formation volume factor data in the CRD were compiled at the province level from the National assessment of geologic $\mathrm{CO}_{2}$ storage (U.S. Geological Survey Geologic Carbon Dioxide Storage Resources Assessment Team, 2013). Temperature and pressure data were provided by Marc Buursink (USGS, written commun., 2013) and formation volume factor data were provided by Hossein Jahediesfanjani (contractor with USGS, written commun., 2013). The data were used to limit the calculated formation volume factor and to fill in missing pressure and temperature values.
- Gas contaminates data-Supplemented from the USGS Energy Resources Program Geochemistry Database (2014). Reservoir contaminates included in the CRD module are carbon dioxide $\left(\mathrm{CO}_{2}\right)$ in 34 States, hydrogen sulfide $\left(\mathrm{H}_{2} \mathrm{~S}\right)$ in 18 States, and nitrogen $\left(\mathrm{N}_{2}\right)$ in 33 States. In addition to state level averages, a Nation average is calculated for each contaminant. These were used to fill in missing properties for the gas reservoirs contained in the NRG database.

\section{Data Preparation}

To prepare the CRD, (1) average reservoir properties are calculated, (2) the reservoirs are characterized as either oil or gas, (3) the petrophysical properties are calculated and validated for consistency and completeness (as discussed in sections below on oil and gas reservoir properties), (4) the production and well counts are updated, (5) the final resource characterization is completed, and (6) the reservoirs are screened to determine candidates for $\mathrm{CO}_{2}$ flooding. This section provides details on the preparation of the data. In each step of the process, a "shadow" value is assigned that identifies the data source for each property (NRG database, IHS data, or supplemental data).

\section{Geographic Regions}

To ensure completeness of the CRD, the algorithm calculates average values for several volumetric properties. These averages are calculated at the following levels:

- Play

- Province

- Region

- Nation

The reservoirs in the CRD are classified by the plays, provinces, and regions based on definitions from the USGS 1995 National Oil and Gas Assessment (NOGA) (Beeman and others, 1996). Maps of the provinces and regions are provided in figure 3.

\section{Calculating Averages}

Table 7 provides a list of the properties which are calculated for three reservoir categories: (1) oil and gas reservoirs, (2) oil reservoirs, and (3) gas reservoirs. Averages are calculated for properties that apply to both oil and gas reservoirs and for properties that are specific to either oil reservoirs or gas reservoirs. The averages that apply to both oil and gas reservoirs are calculated before the averages for either oil reservoirs or gas reservoirs. The averages that are specific to either oil reservoirs or gas reservoirs are calculated after the initial reservoir type has been determined. 
$\boldsymbol{A}$

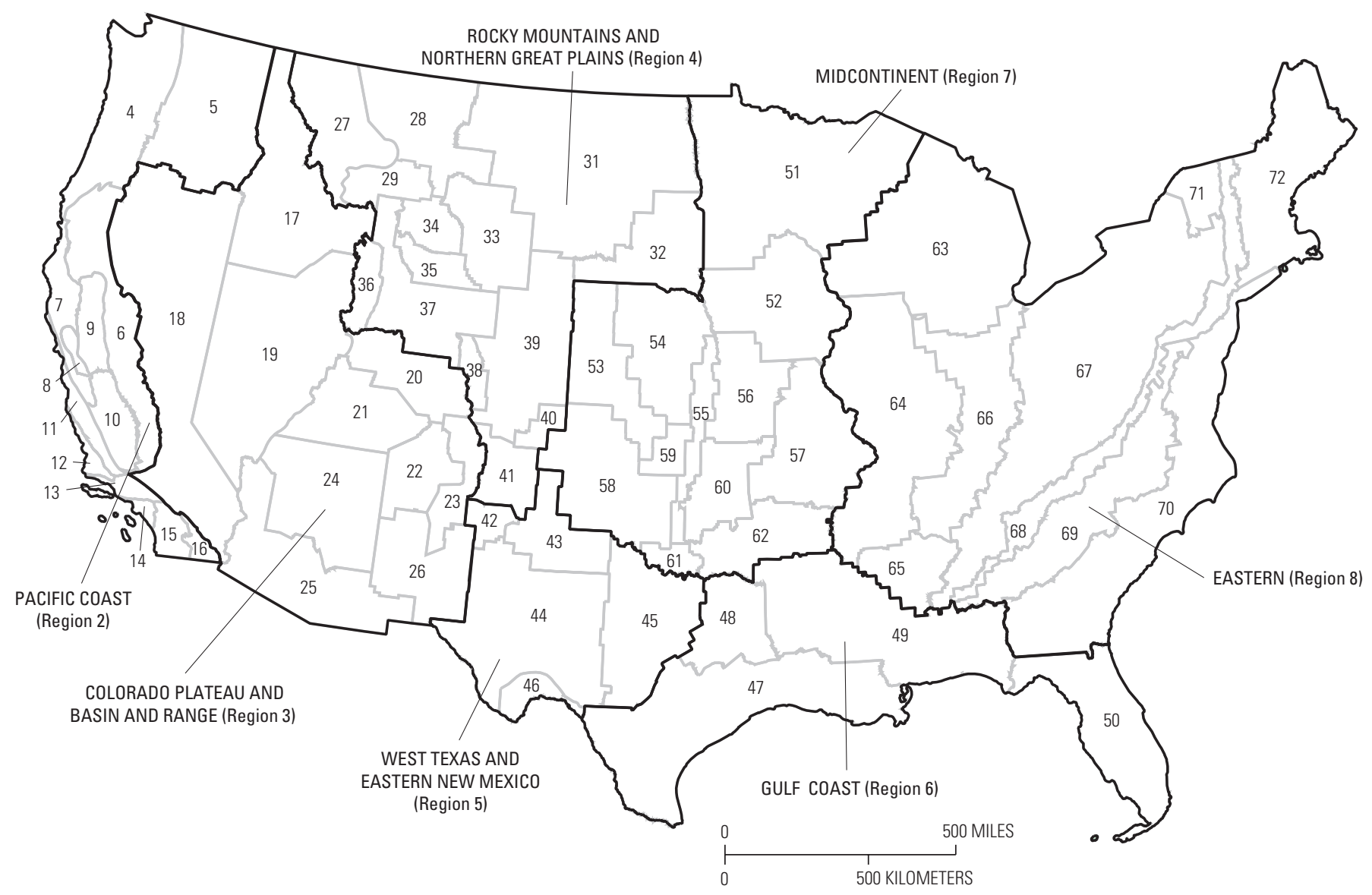

B

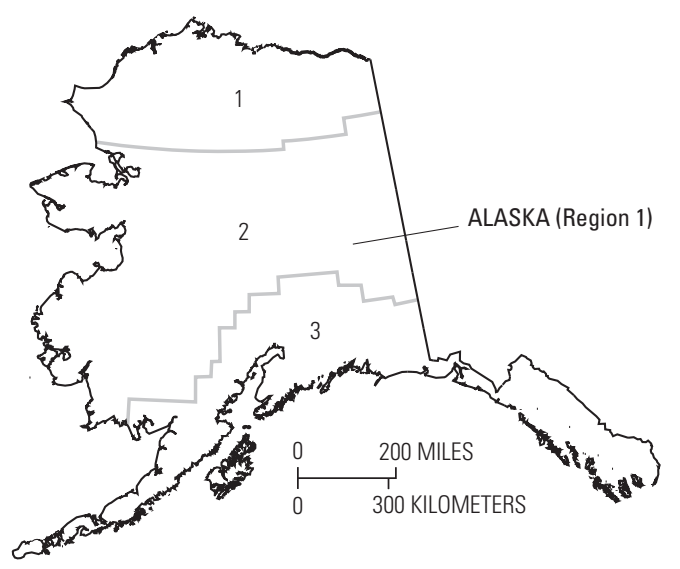

Figure 3. Maps showing the petroleum regions and provinces of the conterminous United States and Alaska. A, Petroleum regions and provinces in onshore and State offshore areas in the conterminous United States. Heavy lines are region boundaries; lighter lines are province boundaries. $B$, Petroleum provinces of the onshore and State offshore areas of Alaska. Regions and provinces shown in figures $3 A$ and $3 B$ are listed by name and number in table 6. From the U.S. Geological Survey's 1995 National Oil and Gas Assessment (NOGA) (Beeman and others, 1996; Attanasi, 1998). 
Table 6. List of petroleum regions and provinces of onshore and State offshore areas in the conterminous United States and Alaska.

[From the U.S. Geological Survey's 1995 National Oil and Gas Assessment (NOGA) (Beeman and others, 1996; Attanasi, 1998). Province numbers have leading zeros as shown below; to save space, those zeros are not shown in figure 3]

\begin{tabular}{|c|c|}
\hline Province number & Province name \\
\hline \multicolumn{2}{|r|}{ Region 1-Alaska } \\
\hline 001 & Northern Alaska \\
\hline 002 & Central Alaska \\
\hline \multirow[t]{2}{*}{003} & Southern Alaska \\
\hline & Region 2-Pacific Coast \\
\hline 004 & Western Oregon-Washington \\
\hline 005 & Eastern Oregon-Washington \\
\hline 006 & Klamath-Sierra Nevada \\
\hline 007 & Northern Coastal \\
\hline 008 & Sonoma-Livermore basin \\
\hline 009 & Sacramento basin \\
\hline 010 & San Joaquin basin \\
\hline 011 & Central Coastal \\
\hline 012 & Santa Maria basin \\
\hline 013 & Ventura basin \\
\hline 014 & Los Angeles basin \\
\hline 015 & San Diego-Oceanside \\
\hline 016 & Salton trough \\
\hline \multicolumn{2}{|c|}{ Region 3-Colorado Plateau and Basin and Range } \\
\hline 017 & Idaho-Snake River downwarp \\
\hline 018 & Western Great basin \\
\hline 019 & Eastern Great basin \\
\hline 020 & Uinta-Piceance basin \\
\hline 021 & Paradox basin \\
\hline 022 & San Juan basin \\
\hline 023 & Albuquerque-Santa Fe rift \\
\hline 024 & Northern Arizona \\
\hline 025 & $\begin{array}{l}\text { Southern Arizona-Southwestern New } \\
\text { Mexico }\end{array}$ \\
\hline 026 & South-central New Mexico \\
\hline \multicolumn{2}{|c|}{ Region 4-Rocky Mountains and Northern Great Plains } \\
\hline 027 & Montana thrust belt \\
\hline 028 & Central Montana \\
\hline 029 & Southwest Montana \\
\hline 031 & Williston basin \\
\hline 032 & Sioux arch \\
\hline 033 & Powder River Basin \\
\hline 034 & Big Horn basin \\
\hline 035 & Wind River Basin \\
\hline 036 & Wyoming thrust belt \\
\hline
\end{tabular}

\begin{tabular}{|c|c|}
\hline Province number & Province name \\
\hline \multicolumn{2}{|c|}{ Region 4-Rocky Mountains and Northern Great Plains-Continued } \\
\hline 037 & Southwest Wyoming \\
\hline 038 & Park basins \\
\hline 039 & Denver basin \\
\hline 040 & Las Animas arch \\
\hline 041 & Raton Basin-Sierra Grande uplift \\
\hline \multicolumn{2}{|c|}{ Region 5-West Texas and Eastern New Mexico } \\
\hline 042 & Pedernal uplift \\
\hline 043 & Palo Duro basin \\
\hline 044 & Permian basin \\
\hline 045 & Bend Arch-Fort Worth basin \\
\hline 046 & Marathon thrust belt \\
\hline \multicolumn{2}{|r|}{ Region 6-Gulf Coast } \\
\hline 047 & Western Gulf \\
\hline 048 & East Texas basin \\
\hline 049 & Louisiana-Mississippi salt basins \\
\hline 050 & Florida Peninsula \\
\hline \multicolumn{2}{|r|}{ Region 7-Midcontinent } \\
\hline 051 & Superior \\
\hline 052 & Iowa Shelf \\
\hline 053 & Cambridge arch-central Kansas \\
\hline 054 & Salina basin \\
\hline 055 & Nemaha uplift \\
\hline 056 & Forest City basin \\
\hline 057 & Ozark uplift \\
\hline 058 & Anadarko basin \\
\hline 059 & Sedgwick basin \\
\hline 060 & Cherokee basin \\
\hline 061 & Southern Oklahoma \\
\hline 062 & Arkoma basin \\
\hline \multicolumn{2}{|r|}{ Region 8-Eastern } \\
\hline 063 & Michigan basin \\
\hline 064 & Illinois basin \\
\hline 065 & Black Warrior basin \\
\hline 066 & Cincinnati arch \\
\hline 067 & Appalachian basin \\
\hline 068 & Blue Ridge thrust belt \\
\hline 069 & Piedmont \\
\hline 070 & Atlantic Coastal Plain \\
\hline
\end{tabular}


Table 7. Average reservoir properties calculated for the Comprehensive Resource Database (CRD).

[Abbreviations: API, American Petroleum Institute; $\mathrm{CO}_{2}$, carbon dioxide; $\mathrm{H}_{2} \mathrm{~S}$, hydrogen sulfide; $\mathrm{N}_{2}$, nitrogen]

\begin{tabular}{lll}
\hline \multicolumn{1}{c}{ Oil and gas reservoirs } & \multicolumn{1}{c}{ Oil reservoirs } & \multicolumn{1}{c}{ Gas reservoirs } \\
\hline Net pay (thickness) & Initial oil saturation & Initial gas saturation \\
Depth & Initial water saturation & Initial water saturation \\
Temperature gradient & Initial formation volume factor & $\mathrm{CO}_{2}$ concentration \\
Pressure gradient & API gravity of oil & $\mathrm{N}_{2}$ concentration \\
Porosity & Specific gravity of the gas & $\mathrm{H}_{2} \mathrm{~S}$ concentration \\
Permeability & Well spacing & Specific gravity of the gas \\
& Sulfur content & Heat content \\
& & Sulfur content \\
\hline
\end{tabular}

Step 1

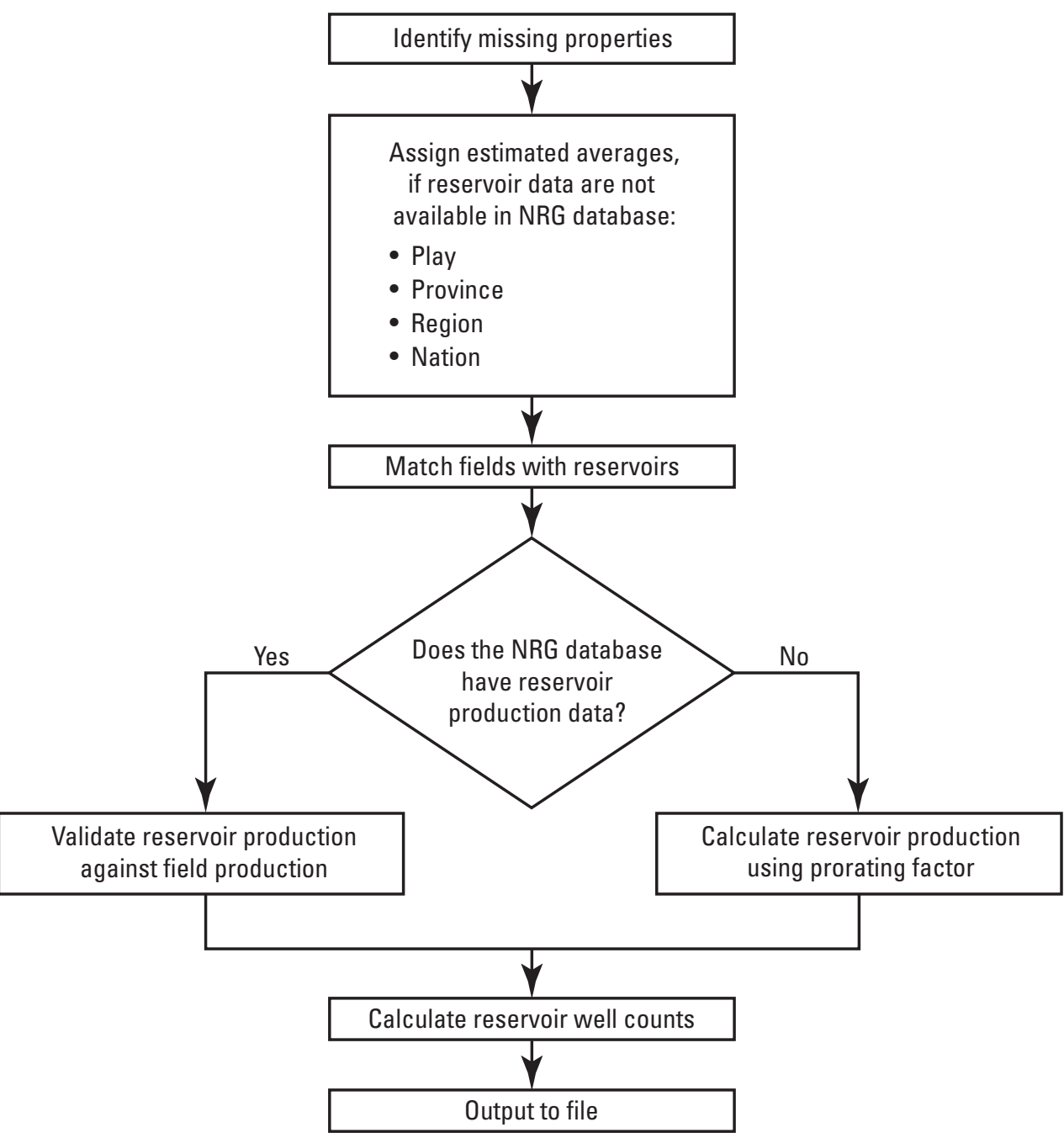

Figure 4. Chart showing the steps taken to estimate missing reservoir production data and the number of active and producing wells (well counts). Abbreviation: NRG, Nehring Associates (2012). 
The averages are calculated in the following manner (equation 1):

$$
\text { playthick }=\frac{\sum \text { thick }}{\text { num_thick }}
$$

where

playthick is the non-zero average thickness of the reservoirs in the play or province, in feet;

thick is the non-zero thickness (in feet), of the reservoir in the play or province; and

num thick is the number of non-zero values in the play or province.

\section{Estimation of Reservoir Production and Well Counts}

The reservoir level database from Nehring Associates (2012) ("NRG") contains production data through 2010. However, it does not provide production data for all reservoirs. In the case where the production data are missing at the reservoir level, it is estimated using the production data contained in the NRG database. After the production is calculated for all reservoirs in the database, the number of active and producing wells is calculated for each reservoir. This section describes the steps taken to estimate the missing reservoir production data and the number of active and producing wells (fig. 4).

The first step shown in figure 4 is to identify the missing properties for oil and gas reservoirs. These properties determine the flow of fluids through the reservoir and include reservoir area, porosity, permeability, net pay thickness, and viscosity. If reservoir data are not available from the NRG database, then they are estimated using the following averages: play, province, region, or Nation (fig. 4, step 2).

The number of reservoirs in the field is determined by counting the number of reservoirs that share a unique field (NRG ID) (fig. 4, step 3) and then validating the reservoir production against the field production (fig. 4, step 4). If any reservoir in the field is missing production data for both oil and gas (fig. 4, step 4), three proration factors are calculated (listed in order of preference in equations 2, 3, and 4) (fig. 4, step 5); however, only one factor is chosen, based on available data:

factor one:

factor two:

factor three:

$$
\text { fact_one }(\text { res })=\frac{\text { area } \times \text { pay } \times \text { porosity } \times \text { permeability }}{\text { viscosity }}
$$

$$
\text { fact_two }(\text { res })=\text { area } \times \text { pay } \times \text { porosity } \times \text { permeability }
$$

where

fact_one(res)

fact_two(res)

is proration factor one;

fact_three(res)

area

pay

porosity

permeability

$$
\text { fact_three }(\text { res })=\text { area } \times \text { pay } \times \text { porosity }
$$

viscosity

is proration factor three;

is the reservoir area, in acres;

is the reservoir productive interval thickness, in feet;

is the reservoir rock porosity, in decimal format;

is the reservoir rock permeability, in millidarcies $(\mathrm{mD})$; and

is the viscosity of the reservoir oil, in centipoise (cP).

After the factors have been calculated for all reservoirs in the field, reservoir distributions are calculated for each factor. The distributions are calculated as shown in equation 5.

where
dist_fact_a,res)
fact_a
res
nres

$$
d i s t_{-}(\text {fact_a,res })=\frac{f a c t \_a(\text { res })}{\sum_{1}^{\text {nres }} f a c t_{-} a(r e s)}
$$




\section{Comprehensive Resource Database for Hydrocarbons Produced by Carbon Dioxide Enhanced Oil Recovery}

The distributions are calculated using a common, complete set of proration factors. The allocation of the field production to the reservoir is determined according to equation 6.

$$
\text { respro }(\text { res, iyr })=d i s t_{-}(\text {fact_a, res }) \times f d a t a(i f l d, i y r)
$$

where

$\begin{aligned} \text { respro(res,iyr) } & \text { is the annual reservoir production of oil, gas, or NGL in year analyzed (iyr); } \\ \text { res } & \text { is the reservoir analyzed; } \\ i y r & \text { is the year analyzed; } \\ \text { dist_(fact_a,res) } & \text { is the reservoir distribution factor; } \\ \text { fact_a } & \text { is reservoir production proration factor one, two, or three; } \\ \text { fdata(ifld,iyr) } & \text { is the annual field production of oil, gas, or NGL in year analyzed (iyr); and } \\ \text { ifld } & \text { is the field that is matched to the reservoir. }\end{aligned}$

If reservoir production data are absent for all reservoirs in the field, or a complete set of proration factors cannot be calculated for all reservoirs matched to the field, then the production is prorated evenly among all reservoirs in the field (equation 7).

$$
\text { respro }(\text { res, iyr })=\frac{\text { fdata }(\text { ifld }, \text { iyr })}{\text { nres }}
$$

where

$$
\begin{aligned}
\text { respro(res,iyr) } & \text { is the annual reservoir production of oil, gas, or NGL in year analyzed (iyr); } \\
\text { res } & \text { is the reservoir analyzed; } \\
\text { iyr } & \text { is the year analyzed; } \\
\text { fdata(ifld,iyr) } & \text { is the annual field production of oil, gas, or NGL in year analyzed (iyr); } \\
\text { ifld } & \text { is the field that is matched to the reservoir; and } \\
\text { nres } & \text { is the number of reservoirs in the field. }
\end{aligned}
$$

After the production is calculated for all reservoirs in the database, the number of active and producing wells (well counts) is calculated for each reservoir (fig. 4, step 6). As the well counts are provided only at the field level, they are prorated for each reservoir. The proration factors are calculated according to the distribution of production (in barrels of oil equivalent, BOE) for each reservoir in the field (equation 8).

where

$$
\operatorname{reswell}(\text { res, iyr })=\frac{\text { respro }(\text { res }, \text { iyr })}{\sum_{r e s=1}^{\text {reses }} \operatorname{respro}(\text { res }, i y r)} \times \text { fldwell }(\text { ifld }, i y r)
$$

\footnotetext{
reswell(res,iyr) is the annual number of wells in the reservoir in year analyzed (iyr);

res is the reservoir analyzed;

iyr is the year analyzed;

respro(res,iyr) is the annual production of oil, gas, or NGL converted to BOE in year analyzed (iyr);

nres is the number of reservoirs in the field;

fldwell(ifld,iyr) is the annual number of wells in the field in year analyzed (iyr); and

ifld is the field that is matched to the reservoir.
}

The number of prorated wells is then rounded to the nearest integer. Additional steps, such as ensuring that there is a well in each year with production, are applied to ensure the reasonableness of the well count. The reservoir production data and the number of active and producing wells (well counts) are written to the CRD file (fig. 4, step 7). 


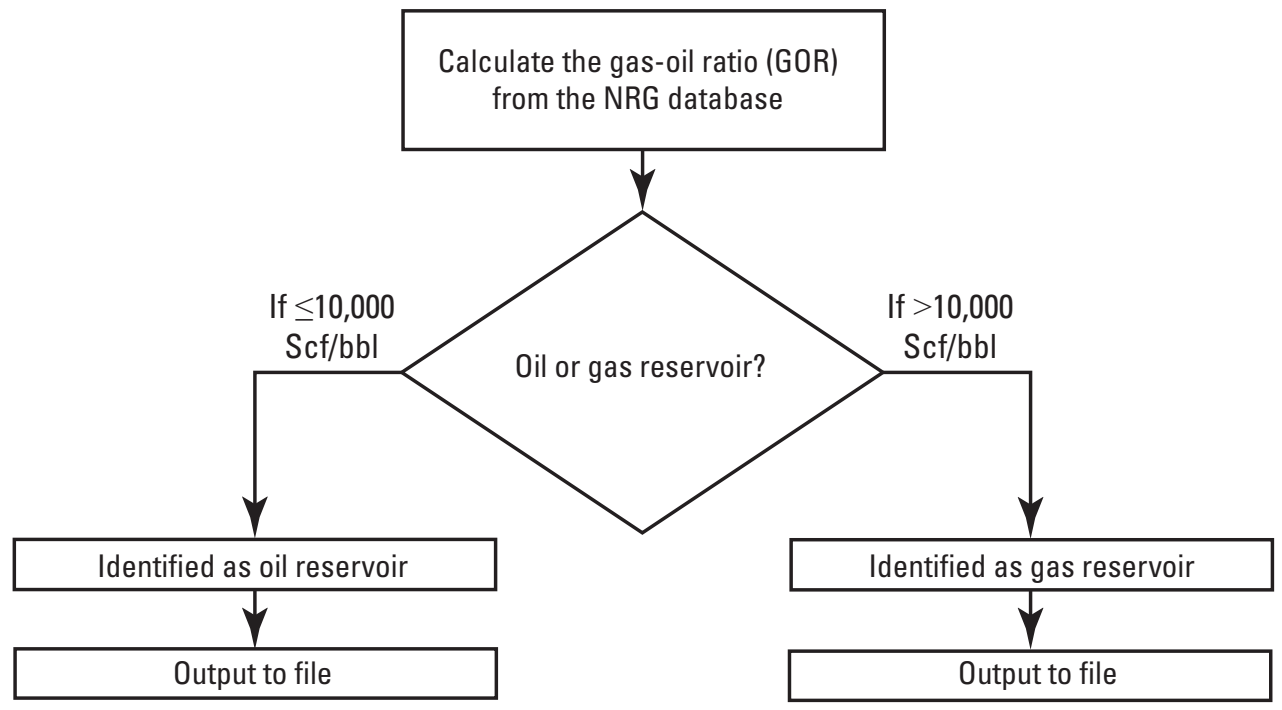

Figure 5. Flowchart showing the process for identifying reservoir type (oil or gas reservoir). Abbreviations: NRG, Nehring Associates (2012); Scf/bbl, standard cubic feet per barrel.

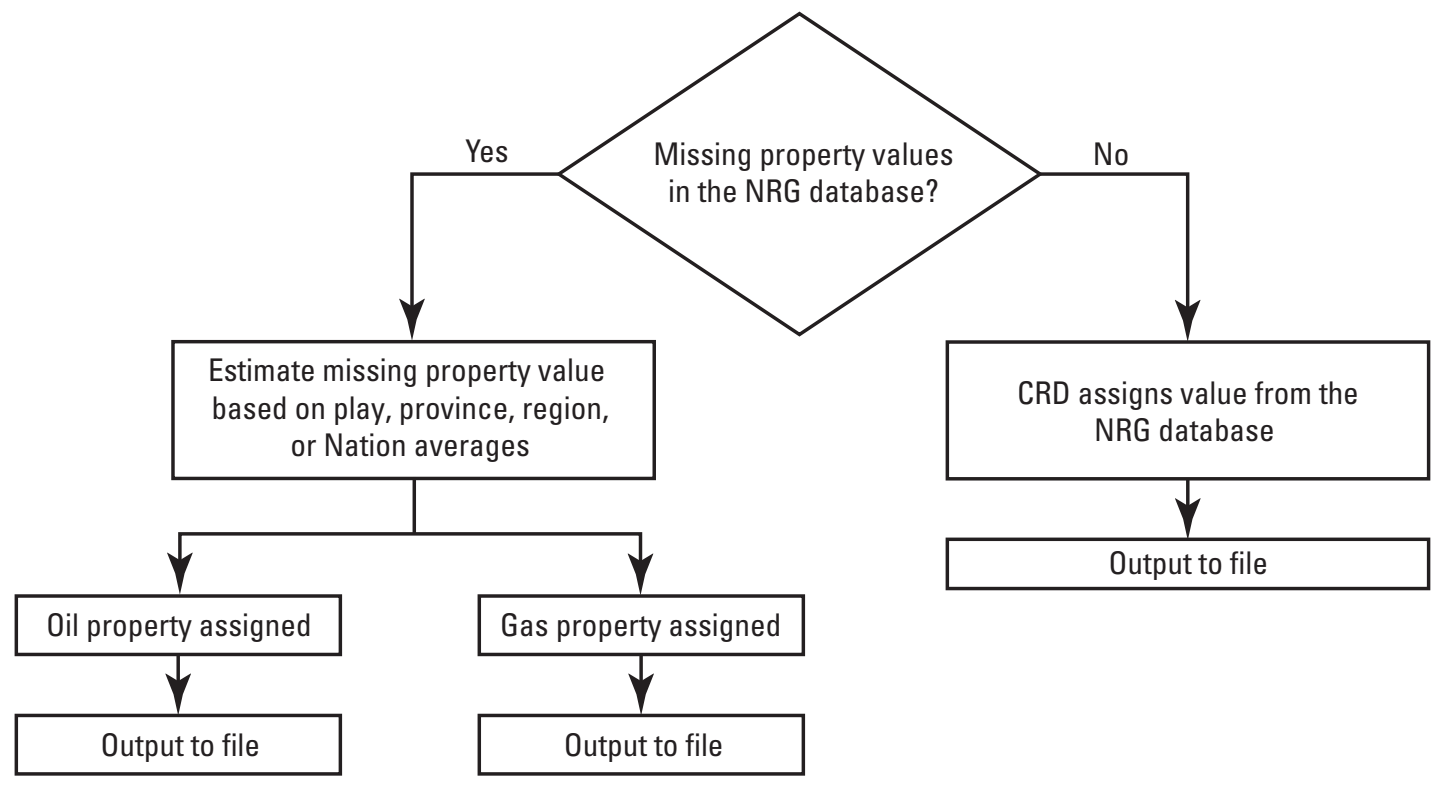

Figure 6. Flowchart showing the steps taken to estimate and calculate oil and gas property values. Abbreviations: CRD, Comprehensive Resource Database; NRG, Nehring Associates (2012).

\section{Identify Reservoir Type}

Next, as illustrated in figure 5, the reservoirs are classified as one of two types:

- Oil reservoir

- Gas reservoir

Such classification uses a calculated gas-oil ratio (GOR) based on the cumulative oil and gas production from the NRG database (fig. 5). For the purposes of EOR screening, a GOR of $10,000 \mathrm{Scf} / \mathrm{bbl}$ or less is used to define oil reservoirs and a GOR of greater than $10,000 \mathrm{Scf} / \mathrm{bbl}$ is used to define gas reservoirs. In addition, the list of existing $\mathrm{CO}_{2}$-EOR projects (Koottungal, 2012, 2014) is used to indicate the active projects and whether the project is a miscible or immiscible $\mathrm{CO}_{2}$ flood. During the initial reservoir type screening (fig. 5), the reservoirs are not classified as active or abandoned. This is determined after the production and well data is updated using the IHS Inc. (2012) data. 


\section{Assignment of Database Values}

Next, the values of petrophysical properties for each oil and gas reservoir are checked for completeness and internal consistency. If values for the properties listed in table 7 are missing in the NRG database (fig. 6), the program estimates those values for oil or gas reservoirs using play, province, region, or Nation averages. Table 2 lists the properties for which the values are calculated or estimated as default values. Figure 6 shows the steps taken to estimate or calculate oil and gas property values.

The defaults used for estimating missing property values are derived from play, province, region, or Nation averages according to the steps provided below. Play averages are used for 28 percent of reservoir attribute records for over 22,000 reservoirs. If the reservoirs are weighted by known recovery of oil, then less than 11 percent of the oil resource uses a play average, 1.2 percent uses a province average, and 0.2 percent uses a region average. Other missing property values are estimated by calculations based on known physical relationships (not shown in fig. 6). In table 2, the missing property values that are estimated by averages are indicated by footnote 1 . Other variables listed are calculated.

Average property values are determined using the following procedure:

Step 1. If the NRG has a value $>0$ (missing property values $=$ "No" in fig. 6), then use the NRG value and output the value to the CRD file;

Step 2. If the NRG value equals 0 (missing property values = "No" in fig. 6), then set to play average;

Step 3. If the NRG value equals 0 and the USGS has additional data, use the USGS data. This step is applicable to pressure and temperature only;

Step 4. If the NRG value is still equal to 0 , then set to province average;

Step 5. If the NRG value is still equal to 0 , then set to region average;

Step 6. If the NRG value is still equal to 0 , then set to Nation average;

Step 7. Output all estimated property values to the CRD file.

In addition, if USGS data are not available, then temperature and pressure require a calculation when using average NRG data.

\section{Temperature}

Step 1. If the NRG has a value greater than 0 , then use the NRG value;

Step 2. If the NRG value is less than or equal to 0 and $N R G$ has values for temperature gradient and depth, then calculate the temperature with equation 9 using the play-level default. If play-level data are not available in the NRG, then region or Nation averages may be used.

$$
\operatorname{Dary}(i, 17)=60+P l y \_ \text {TempGr }(k) \times \operatorname{Dary}(i, 16)
$$

where

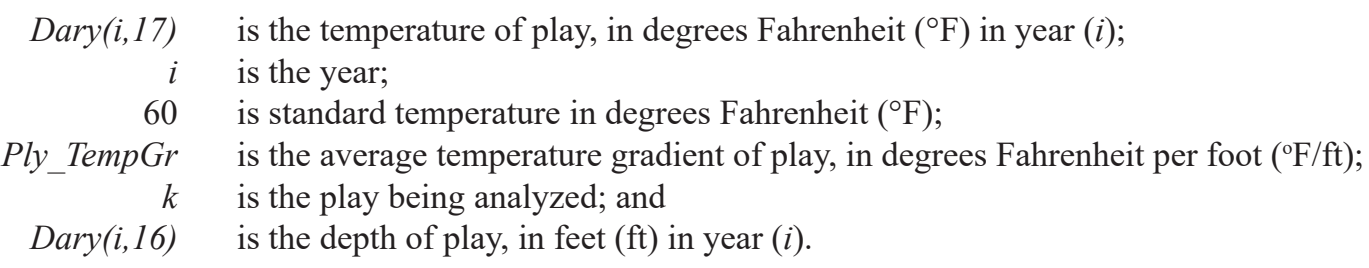

\section{Pressure}

Step 1. If the NRG initial pressure is greater than 80 percent of the calculated pressure, then use the NRG initial pressure;

Step 2. If the NRG initial pressure is less than or equal to 80 percent of the calculated pressure, then use the calculated initial reservoir pressure (Pres Cal). The calculation is shown in equation 10 using the play-level default. If play-level data are not available in the NRG, then region or Nation averages may be used. 


$$
\text { PresCal }=14.7+\text { Ply_PresGr }(k) \times \text { Dary }(i, 16)
$$

where

PresCal is the calculated initial pressure, in pound-force per square inch absolute (psia);

14.7 is standard atmospheric pressure in pound-force per square inch per foot (psi/ft);

Ply_PresGr is the average pressure gradient of play, in pound-force per square inch per foot (psi/ft);

$k \quad$ is the play being analyzed;

$\operatorname{Dary}(i, 16) \quad$ is the depth of play, in feet $(\mathrm{ft})$ in year $(i)$; and

$i$ is the year.

\section{Oil Reservoir Area}

Oil reservoir area is needed to calculate the original oil in place (OOIP) for reservoirs with incomplete OOIP data in the NRG database.

Step 1. If NRG has reservoir area (in acres), then use the NRG area;

Step 2. If NRG reservoir area value is $\leq 0$, then calculate reservoir area using:

$$
\text { Area }=\text { well spacing } \times \text { spacing units }
$$

where

spacing units is the number of wells in each reservoir with equal well spacing.

Step 3. If area is still less than or equal to 0 , then calculate the reservoir area using equation 12 .

$$
\operatorname{OrgArea}(i)=O O I P \times B O I /(7,758 \times \text { NetPay } \times(\text { Porosity } / 100) \times S O I)
$$

where

$\begin{aligned} \text { OrgArea }(i) & \text { is the calculated reservoir area, in acres in year }(i) ; \\ \text { OOIP } & \text { is the original oil in place, in stock tank barrels (STB); } \\ \text { BOI } & \text { is the initial oil formation volume factor, in decimal format; } \\ 7,758 & \text { is the conversion factor from acre-feet to barrels; } \\ \text { NetPay } & \text { is the net reservoir thickness, in feet }(\mathrm{ft}) ; \\ \text { Porosity } & \text { is the porosity of the oil reservoir rock, in percent; and } \\ \text { SOI } & \text { is the initial oil saturation, in decimal format. }\end{aligned}$

Step 4. Then, if the reservoir area is greater than the field area, use equation 13.

$$
\text { Reservoir area }=\text { field area }
$$

\section{Well Spacing} database.

Well spacing is needed to calculate the reservoir area (in acres) for reservoirs with incomplete well spacing data in the NRG

Step 1. If active wells equals 0 , then set the effective well spacing equal to 0 acres;

Step 2. If there are wells, use the number of wells and the active area (in acres) to calculate the well spacing;

Step 3. Estimate the maximum well spacing, in acres:

a. If NRG provides one (of two) well spacing values, use the maximum value;

b. If the calculated value is above the maximum, use the maximum value; 
c. If the well spacing has been estimated in step $3 \mathrm{~b}$, and if NRG provides both well spacing values, use the average value;

Step 4. If no NRG well spacing data are available, then the maximum well spacing is set as 80 acres.

\section{Original Oil in Place}

To verify that the reservoir original oil in place $(O O I P)$ values in the NRG database are reasonable, the NRG OOIP is checked against the reservoir area, the cumulative production, and the estimated NRG known oil recovery (KR $R_{\text {oil }}$, cumulative production plus reported reserves). Reservoir volumetric values are adjusted as necessary before a final OOIP calculation is made. If reservoir area is unknown, and assuming that reservoirs areas are larger than the current production area, then three times the current producing area is an initial attempt to start the iterative process of estimating area when reservoir oil recovery has already exceeded 35 percent of the NRG OOIP. The area was varied in the steps afterwards in order to calculate a more realistic OOIP than the initial OOIP reported in the NRG. The approach uses the following steps to calculate the reservoir OOIP:

Step 1. If the initial oil formation volume factor is missing, then the $O O I P$ is calculated using the reservoir properties;

Step 2. Evaluate the NRG $K R_{\text {oil }}$ :

a. If the $K R_{\text {oil }}$ is less than or equal to 35 percent of the $O O I P$, keep the $O O I P$ without any changes to the volumetric values.

b. If $K R_{\text {oil }}$ is greater than 35 percent of the $O O I P$, then adjust the variables as follows:

i. Determine the maximum area: three times the current producing area or field area;

ii. Estimate the area necessary for a 35 percent recovery factor;

iii. If the estimated area is less than or equal to the maximum area, then set the NRG area equal to the estimated area, or;

Step 3. If the estimated area is greater than the maximum area, then set the NRG area equal to the maximum area and check NetPay, Porosity, SOI, and BOI, assuming an equal contribution of the difference and adjusting NetPay last;

Step 4. Allow up to 10 percent change in any of the parameters;

Step 5. Check that the revised values are within the range for the play. For example, for a given play, the minimum $S O I$ is $\leq$ calculated $S O I$ is $\leq$ maximum $S O I$.

Step 6. Recalculate OOIP using a recalculated $\operatorname{OrgArea}(i)$ using equations 14 to 16 :

$$
\text { AreaOOIP }=K R_{\text {oil }} \times 0.35
$$

where

AreaOOIP is the calculated recoverable original oil in place, in thousands of stock tank barrels (MSTB);

$K R_{\text {oil }} \quad$ is the NRG known oil recovery (cumulative production plus reported reserves, in thousands of barrels $[\mathrm{Mbbl}])$; and

0.35 is an assumed 35 percent reservoir recovery factor.

$$
\text { OrgArea }(i)=\text { AreaOOIP } \times \text { BOI } /(7,758 \times \text { NetPay } \times(\text { Porosity } / 100) \times S O I)
$$

where

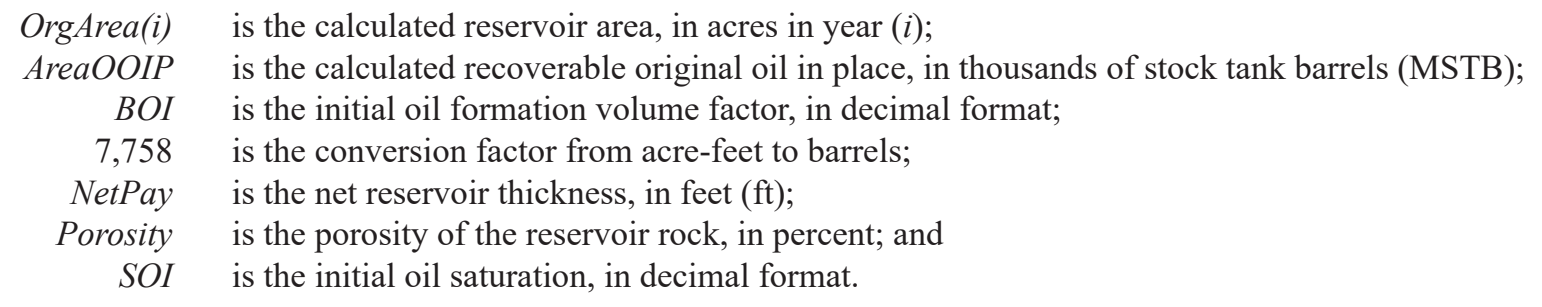




$$
\text { OOIP }=(7,758 \times \text { OrgArea }(i) \times \text { NetPay } \times(\text { Porosity } / 100) \times \text { SOI }) / \text { BOI }
$$

where

OOIP is the original oil in place, in stock tank barrels (STB);

7,758 is the conversion factor from acre-feet to barrels (bbl);

OrgArea $(i)$ is the calculated reservoir area, in acres in year $(i)$;

NetPay is the net reservoir thickness, in feet (ft);

Porosity is the porosity of the reservoir rock, in percent;

$S O I$ is the initial oil saturation, in decimal format; and

$B O I$ is the initial oil formation volume factor, in decimal format.

\section{Critical Gas Reservoir Properties}

Critical NRG gas reservoir properties that require estimates of missing data include (1) well spacing, (2) gas-in-place volume, (3) recovery factor, and (4) producing area. The process of estimating each property is described below.

1. Reservoir well spacing is estimated using the following steps:

Step 1. If the number of total wells is equal to 0 , set the well spacing equal to 0 acres;

Step 2. Use well-spacing data provided by the NRG database; check that the well spacing is between 80 and 320 acres. If the well spacing is less than 80 acres, it is set equal to 80 acres. If well spacing is greater than 320 acres, it is set equal to 320 acres.

2. Reservoir gas-in-place volume per unit area $(G I P V O L)$ is estimated using the following steps:

Step 1. Calculate the gas compressibility factor (Z factor) following methods described in Standing and Katz (1942) and Wichert and Aziz (1971) using the gas specific gravity, its content of carbon dioxide $\left(\mathrm{CO}_{2}\right)$ and hydrogen sulfide $\left(\mathrm{H}_{2} \mathrm{~S}\right)$, reservoir pressure, and reservoir temperature;

Step 2. Use the calculated Z factor to calculate the GIPVOL as shown in equation 17:

$$
\text { GIPVOL }=\frac{43,560 \times \text { Por } \times \text { NetPay } \times \text { SGI }}{0.02829 \times \text { Zfactor } \times(\text { Tres }+460)} \times \text { PRESIN }
$$

where

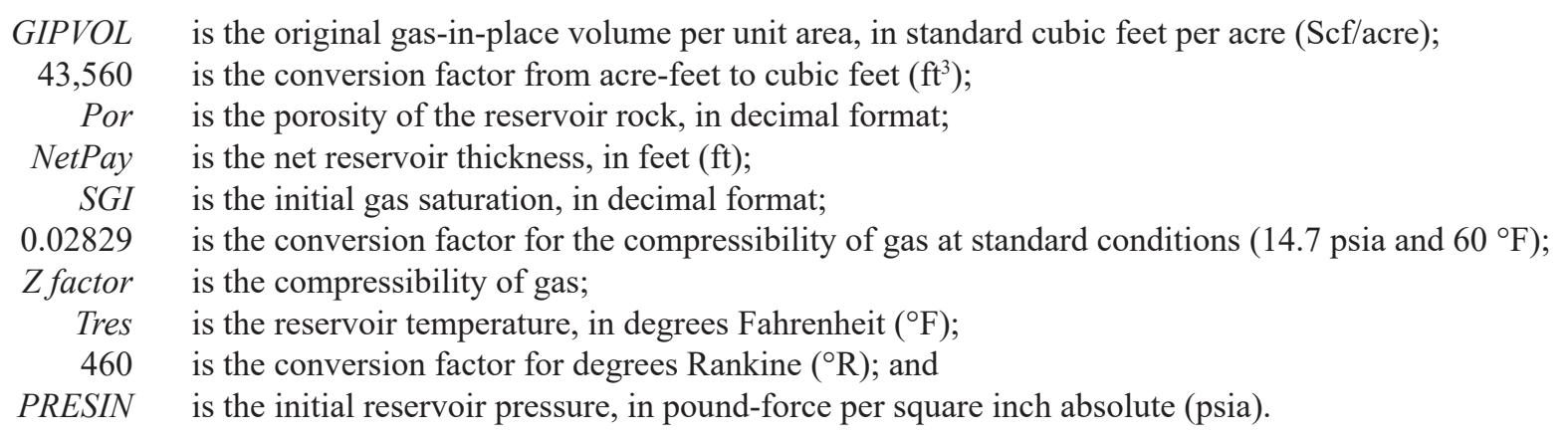

3. The recovery factor is estimated using the NRG known gas recovery $\left(K R_{\text {gas }}\right)$ and the original gas in place $(O G I P)$ in the following steps:

Step 1. Divide the $K R_{\text {gas }}$ by the $O G I P$;

Step 2. If the reservoir is conventional, and

- If the estimated ultimate recovery $(E U R)$ is greater than 80 percent, set the recovery factor equal to 0.8 ;

- If the EUR is less than 40 percent, set the recovery factor equal to 0.4 .

Step 3. If the reservoir is coal or shale, and 
- If the EUR is greater than 30 percent, set the recovery factor equal to 0.3 ;

- If the $E U R$ is less than 10 percent, set the recovery factor equal to 0.1 .

4. The reservoir producing area is estimated using one of the following sequence of steps; if data are not available for an individual step, then the next step is used until the reservoir producing area has been estimated:

Step 1. Use the gas reservoir area provided by NRG, or;

Step 2. Use the number of wells and the well spacing provided by NRG to calculate the reservoir area, or;

Step 3. Use the number of wells and the calculated well spacing to calculate the reservoir area, or;

Step 4. Assume that there is only one well per 40 acres.

Figure 7. Flowchart showing the process steps for updating Nehring Associates (2012) production and well-count data with IHS Inc. (2012) field production and well-count data. State production data are from the U.S. Energy Information Administration (EIA, 2013a, b). Abbreviations: IHS, IHS Inc. (2012); NRG, Nehring Associates (2012).
Step 1

Step 3

Step 5

Update NRG oil and gas database

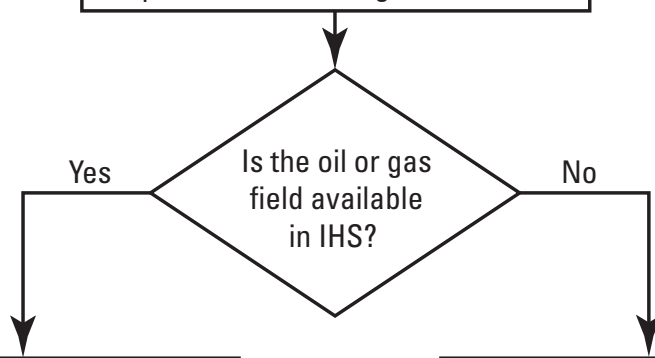

Step 2

Match IHS and NRG reservoir and field production data

Update with prorated State production data from EIA

Step 4

Step 6

Step 7

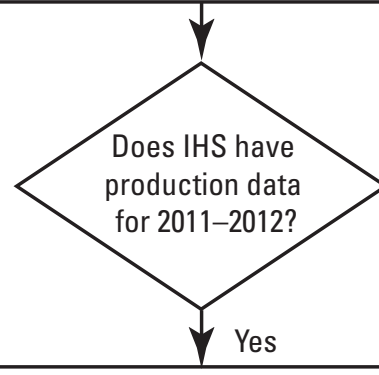

Prorate IHS production data to reservoir data using 2008-2010 NRG production data
Assume no production in that year 


\section{Updating with IHS Data}

As previously discussed, the NRG database production and well-count data are current through 2010 . To update the data to 2012 in the CRD, the NRG database is supplemented by the IHS field production and well-count data. The major steps of this process are illustrated in figure 7 and described in this section.

Some NRG oil or gas fields that do not have IHS production data available are not subject to be updated, and no further supplementation of these fields is possible. A list of these oil or gas fields that do not have IHS data available is noted in a separate file in the CRD.

The following steps are for updating NRG production and well-count data with IHS data:

Step 1. Determine whether the IHS oil or gas field data are available. If data are not available from IHS, then the NRG production data for the CRD will be updated with prorated State production data from the U.S. Energy Information Administration (2013a, b);

Step 2. If data are available from IHS, then match IHS field and production data with NRG reservoir and field production data;

Step 3. Determine if IHS production data are available for 2011 and 2012. If no data are available for one or both years, then assume no production in that year;

Step 4. Determine how many reservoirs (and which reservoirs) are matched to the oil or gas field. For each reservoir, prorate the updated IHS oil or gas field production data using ratios calculated from the last three years (2008-2010) of the NRG production data (equation 18). A three-year period was selected in order to capture the recent production trends of the reservoirs within the field.

where

$$
\text { respro }(\text { res }, \text { iyr })=\frac{\text { crespro }(\text { res })}{\sum_{\text {res }=1}^{\text {nres }} \operatorname{crespro}(\text { res })} \times \text { ihsprod }(\text { ifld }, \text { iyr })
$$

respro is the annual reservoir oil or gas production, in thousands of barrels (Mbbl) or millions of cubic feet (MMcf);

res is the reservoir analyzed;

iyr is the year analyzed;

crespro is the NRG cumulative production of the reservoir (2008-2010), in thousands of barrels (Mbbl) or billions of cubic feet (Bcf);

nres is the number of reservoirs in the field;

ihsprod is the IHS Inc. (2012) (IHS) annual oil or gas production from the field, in thousands of barrels (Mbbl) or millions of cubic feet (MMcf); and

ifld is the field that is matched to the reservoir.

Step 5. After the production has been updated, the reservoir level well count (number of wells) is also updated, using equation 19.

where

$$
\operatorname{reswell}(\text { res }, i y r)=\frac{\operatorname{resprod}(\text { res }, i y r)}{\sum_{r e s=1}^{n r e s} \operatorname{resprod}(r e s, i y r)} \times f l d w e l l(i f l d, i y r)
$$

reswell(res,iyr) is the annual number of wells in the reservoir in year analyzed (iyr);

res is the reservoir analyzed;

iyr is the year analyzed;

resprod(res,iyr) is the annual production of oil and gas, converted to barrels of oil equivalent (BOE) in year analyzed (iyr); nres is the number of reservoirs in the field;

fldwell(ifld,iyr) is the annual number of wells in the field in year analyzed (iyr); and

ifld is the field that is matched to the reservoir.

As in the previous step, the number of wells is converted to an integer and the results are checked for errors.

Step 6. Assign reservoir type as oil, gas, or abandoned; 
Step 7. Update the NRG reservoir properties;

Step 8. Output the updated production data to a file for use in the CRD.

\section{Assigning Final Reservoir Type}

The updated production data is used to recalculate the gas-oil ratio (GOR) for the reservoir, and the final reservoir type is determined.

Three categories are considered for the final reservoir type assignment:

- Oil reservoir, if GOR is less than or equal to 10,000 $\mathrm{Scf} / \mathrm{bbl}$;

- Gas reservoir, if GOR is greater than $10,000 \mathrm{Scf} / \mathrm{bbl}$;

- Abandoned reservoir, if no production is available in the last three years of data.

The oil and abandoned reservoirs are considered for $\mathrm{CO}_{2}-$ EOR in the Screening Module section of this report.

\section{Updating Properties}

In addition to updating the production and the well counts (discussed previously), several reservoir properties are updated in the NRG database (that is updated for the CRD) using IHS data. These properties are listed in table 8 .

\section{Screening Module}

The screening module determines the potential oil and abandoned reservoirs, which are candidates for miscible and immiscible $\mathrm{CO}_{2}$-EOR flooding. When $\mathrm{CO}_{2}$ is injected under conditions of miscibility, the $\mathrm{CO}_{2}$ aids in the recovery of oil by (1) swelling the crude oil, (2) lowering the viscosity of crude oil, and by (3) miscible displacement of the oil when the reservoir pressure is at least equal to the minimum miscibility pressure (MMP). When miscibility of two fluids occurs, the fluids are mixed with no interface between them. Miscibility of $\mathrm{CO}_{2}$ with oil does not generally occur at the first contact, but will occur along multiple contacts if the MMP is maintained in the reservoir (Taber and others, 1997). Minimum miscibility pressure depends on the reservoir temperature, pressure, and oil composition and is calculated using curves based on experimental data that were constructed by Holm and Josendal (1974) and Mungan (1981). The curves from figure 3 of Mungan (1981) were digitized and for the CRD, the MMP was calculated by interpolation of Mungan (1981) curve values based on the CRD reservoir temperature and the molecular weight of pentanes and heavier fractions of the reservoir's oil. A list of all applied screening criteria for miscible and immiscible flooding is provided in table 9 .

\section{Outputs}

The program code that generates the CRD creates 14 major outputs. These outputs contain the properties and production data for the various reservoirs evaluated by the screening criteria (table 9). Table 10 lists 14 major output files and provides a brief description of each. Included in these 14 output files that the module creates is a series of 5 "shadow" output files. The 5 shadow files identify the data sources that are used for every property value of every reservoir. These files can be used to track how the CRD computer model filled in missing property values, when an average or default was used, and if the original NRG value is retained.

Table 8. List of reservoir properties that are updated with IHS Inc. (2012) data after the final reservoir type assignment.

\begin{tabular}{ll}
\hline \multicolumn{1}{c}{ Oil and abandoned reservoirs } & \multicolumn{1}{c}{ Gas reservoirs } \\
\hline Current oil saturation $(S O C)$ & Current gas saturation $(S G C)$ \\
Current water saturation $(S W C)$ & Current water saturation $(S W C)$ \\
Gas-oil ratio $(G O R)$ & Condensate-to-gas ratio \\
Producing wells & Producing wells \\
Injection wells & Injection wells \\
Total wells & Total wells \\
Well spacing & Well spacing \\
Cumulative production & Cumulative production \\
Current oil formation volume factor $(B O C)$ & Current gas formation volume factor $(B G C)$ \\
& Current pressure \\
& Current temperature \\
\hline
\end{tabular}


Table 9. Screening criteria for miscible and immiscible flooding.

[Abbreviations: API, American Petroleum Institute; ${ }^{\circ} \mathrm{API}$, degrees API; cP, centipoise; ft, feet; psi, pound-force per square inch]

\begin{tabular}{lccc}
\hline \multicolumn{1}{c}{$\begin{array}{c}\text { Screening criteria } \\
\text { properties (units) }\end{array}$} & Miscible flooding & Transitional & Immiscible flooding \\
\hline API gravity of oil ( $\left.{ }^{\circ} \mathrm{API}\right)$ & ${ }^{1}>25$ & $22>$ API $\leq 25$ & $213 \leq \mathrm{API} \leq 22$ \\
Viscosity (cP) & ${ }^{3}<10$ & ${ }^{3}<10$ & $<10$ \\
${ }^{4}$ Minimum miscibility pressure (psi) & $\leq$ fracture pressure -400 & $\leq$ fracture pressure -400 & Not applicable \\
\hline
\end{tabular}

${ }^{1}$ National Petroleum Council (1984a).

${ }^{2}$ Hite (2006).

${ }^{3}$ Andrei and others (2010).

${ }^{4}$ To maintain a reasonable level of safety, the minimum miscibility pressure of candidate reservoirs must be at least 400 psi below the reservoir fracture pressure. The $400 \mathrm{psi}$ safety margin is an estimate of current industry practice.

Table 10. Major output files generated in creation of the Comprehensive Resource Database (CRD).

[Abbreviations: IHS, IHS Inc. (2012); NRG, Nehring Associates (2012) database]

\begin{tabular}{ll}
\hline \multicolumn{1}{c}{ File name } & \\
\hline Reservoir.out & Reservoirs with backfilled/updated data; contain data based on both NRG and IHS files. \\
Hypothetical.out & Reservoirs with backfilled/updated data; contain data based solely on IHS files. \\
Oil.out & All oil reservoirs. \\
Gas.out & All gas reservoirs. \\
Abn.out & All abandoned reservoirs. \\
Immiscible_pot.out & Active oil reservoirs eligible for immiscible flooding. \\
Immiscible_abn.out & Abandoned reservoirs eligible for immiscible flooding. \\
Miscible_pot.out & Active oil reservoirs eligible for miscible flooding. \\
Miscible_abn.out & Abandoned reservoirs eligible for miscible flooding. \\
Shadowdata.out & Maps changes in database property values; corresponds to reservoir.out. \\
Shadowhypo.out & Maps changes in database property values; corresponds to hypothetical.out. \\
Shadowoil.out & Contains the "shadow" property values for oil.out. \\
Shadowgas.out & Contains the "shadow" property values for gas.out. \\
Shadowabn.out & Contains the "shadow" property values for abn.out. \\
\hline
\end{tabular}




\section{Additional Fluid Properties in Oil Reservoirs}

Current reservoir pressure (PRESC) is the current pressure in the reservoir after production or waterflood operations. Current reservoir pressure is calculated using equation 20:

$$
\text { PRESC }=(0.433 \times D E P T H)+14.7
$$

where

PRESC is the current reservoir pressure, in pound-force per square inch absolute (psia);

0.433 is the normal hydrostatic pressure gradient for freshwater in pound-force per square inch per foot (psi/ft);

$D E P T H \quad$ is the reservoir depth, in feet (ft); and

14.7 is the standard atmospheric pressure, in pound-force per square inch (psi).

However, if the initial pressure is less than current pressure, then current pressure is set equal to 90 percent of initial pressure.

Current oil saturation $(S O C)$ is calculated using equation 21:

$$
S O C=S O I \times \frac{\left(1-\frac{\text { cumprod }}{\text { OOIP }}\right)}{\frac{B O C}{B O I}}
$$

where
SOC is the current oil saturation, in decimal format;
SOI is the initial oil saturation, in decimal format;
cumprod is the cumulative oil production, in thousands of barrels (Mbbl);
OOIP is the original oil in place, in thousands of stock tank barrels (MSTB);
$B O C$ is the current oil formation volume factor, in decimal format; and
$B O I$ is the initial oil formation volume factor, in decimal format.

Initial oil formation volume factor $(B O I)$ is from the NRG database, or it is calculated using the methods described in Standing (1948) and Satter and others (2008), as shown in the following steps and equations 22 to 26 :

Step 1. The coefficient $(\mathrm{Yg})$ is calculated for the solution gas-oil ratio equation (equation 22$)$ as:

$$
Y g=0.00091 \times \text { Tres }-0.0125 \times A P I
$$

where
$Y g$ is the coefficient for the solution gas-oil ratio equation;
0.00091 is a constant value obtained from curve fitting by Standing (1948);
Tres is the reservoir temperature, in degrees Fahrenheit $\left({ }^{\circ} \mathrm{F}\right)$;
0.0125 is a constant value obtained from curve fitting by Standing (1948); and
$A P I \quad$ is the American Petroleum Institute gravity of oil, in degrees API ( $\left.{ }^{\circ} \mathrm{API}\right)$.

Step 2. The solution gas-oil ratio $(R S)$ is calculated using equation 23 :

$$
R S=S G G \times\left[\left(P R E S I N /\left(18 \times 10^{Y g}\right)\right]^{1.204}\right.
$$

where

$R S$ is the solution gas-oil ratio, in standard cubic feet per stock tank barrel (Scf/STB);

$S G G \quad$ is the specific gravity of the gas;

PRESIN is the initial reservoir pressure, in pound-force per square inch absolute (psia);

$\mathrm{Yg}$ is the coefficient for the solution gas-oil ratio equation;

18 is a constant obtained by rewriting the Standing correlation equation (Standing, 1948); and

1.204 is a constant obtained by rewriting the Standing correlation equation (Standing, 1948). 
Step 3. The specific gravity of oil $(S G O)$ is calculated using equation 24 :

$$
S G O=141.5 /(131.5+A P I)
$$

where

$S G O \quad$ is the specific gravity of oil; and

$A P I$ is the American Petroleum Institute gravity of oil, in degrees API ( $\left.{ }^{\circ} \mathrm{API}\right)$ and is defined as $(141.5 / S G O$ at $\left.60^{\circ} \mathrm{F}\right)-131.5$.

Step 4. The coefficient $F$ is calculated for the initial oil formation volume factor equation using equation 25 as:

$$
F=R S \times(S G G / S G O)^{0.5}+1.25 \times \text { Tres }
$$

where

$\begin{aligned} F & \text { is the coefficient for the initial oil formation volume factor equation; } \\ R S & \text { is the solution gas-oil ratio, in standard cubic feet per stock tank barrel (Scf/STB); } \\ S G G & \text { is the specific gravity of the gas; } \\ S G O & \text { is the specific gravity of oil; } \\ 0.5 & \text { is a curve-fitting exponent obtained by Standing (1948); } \\ 1.25 & \text { is a constant value obtained from curve fitting by Standing (1948); and } \\ \text { Tres } & \text { is the reservoir temperature, in degrees Fahrenheit }\left({ }^{\circ} \text { F). }\right.\end{aligned}$

Step 5. The initial oil formation volume factor $(B O I)$ is calculated using equation 26 :

$$
B O I=0.972+0.000147 \times F^{1.175}
$$

where

$B O I$ is the initial oil formation volume factor, in decimal format;

0.972 is a constant for the correlation equation developed by Standing (1948) as published in Lyons (1999);

0.000147 is a constant for the correlation equation developed by Standing (1948) as published in Lyons (1999);

$F \quad$ is the coefficient for the initial oil formation volume factor equation; and

1.175 is a constant for the correlation equation developed by Standing (1948) as published in Lyons (1999).

Both Tres and PRESIN, in equations 22 and 23 respectively, are from the NRG database, or calculated using temperature and pressure gradients as discussed in an earlier section (equations 9 and 10).

Specific gravity of the gas $(S G G)$ is provided by the NRG database or is estimated by the play or province average where its value is not provided. If no data are available, the default value of 0.8 is assumed.

Current oil formation volume factor $(B O C)$ can also be calculated using equation 26 by using current reservoir temperature and pressure. If the calculated $B O C$ is equal to or larger than $B O I$, then it is set equal to 99 percent of $B O I$.

Current water saturation $(S W C)$ is calculated using equation 27 :

$$
S W C=1-S O C-S G I
$$

where

SWC is the current water saturation, in decimal format;

$S O C$ is the current oil saturation, in decimal format; and

$S G I$ is the initial gas saturation, in decimal format.

Current gas saturation $(S G C)$ is assumed to be the same as initial gas saturation, unless NRG data have values for initial gas saturation $(S G I)$, then it is calculated using equation 28 :

$$
S G I=1-S O I-S W I
$$

where

SGI is the initial gas saturation, in decimal format;

$S O I$ is the initial oil saturation, in decimal format; and

$S W I$ is the initial water saturation, in decimal format. 


\section{Comprehensive Resource Database for Hydrocarbons Produced by Carbon Dioxide Enhanced Oil Recovery}

Oil viscosity $(\mu)$, if not provided in the NRG data, is calculated by first finding the dead (with no dissolved gas) oil viscosity using the Beggs and Robinson (1975) correlation (equation 29).

Dead oil viscosity $\left(\mu \_D E A D\right)$ is calculated as:

$$
\mu \_\mathrm{DEAD}=10^{x}-1
$$

where

$\mu_{-} D E A D \quad$ is the dead oil viscosity (no dissolved gas), in centipoise (cP); and

$X \quad$ is a dummy variable that relates two other variables ( ${ }^{\circ}$ API gravity of oil and temperature) in a rather complex formula (equation 30), and is defined as:

$$
X=\left[10^{(3.0324-(0.02023 \times A P D)}\right] /\left(\operatorname{Tres}^{1.163}\right)
$$

where

3.0324 is a curve-fitting exponent determined by Beggs and Robinson (1975);

0.02023 is a curve-fitting exponent determined by Beggs and Robinson (1975);

$A P I \quad$ is the American Petroleum Institute gravity of oil, in degrees API ( $\left.{ }^{\circ} \mathrm{API}\right)$;

Tres is the reservoir temperature, in degrees Fahrenheit $\left({ }^{\circ} \mathrm{F}\right)$; and

1.163 is a curve-fitting exponent determined by Beggs and Robinson (1975).

The conversion to live oil (with dissolved gas) is based on Beggs and Robinson (1975), Vasquez and Beggs (1980), and the dead oil viscosity.

The viscosity of live oil $\left(\mu_{-} L I V E\right)$ is calculated using equation 31 :

$$
\mu_{-} L I V E=A \times \mu_{-} D E A D^{B}
$$

where
$\mu_{-}$LIVE $\quad$ is the live oil (with dissolved gas) viscosity, in centipoise (cP);
$A$ is a variable coefficient whose value is determined by the value of the solution gas-oil ratio (Beggs and Robinson, 1975);
$B \quad$ is an exponent determined by the value of the solution gas-oil ratio (Beggs and Robinson, 1975).

$A$ and $B$ are defined in equations 32 and 33 as:

$$
\begin{gathered}
A=10.715 \times(R S+100)^{-0.515} \\
B=5.44 \times(R S+150)^{-0.338}
\end{gathered}
$$

where

$A$ is a variable coefficient whose value is determined by the value of the solution gas-oil ratio (Beggs and Robinson, 1975);

10.715 is a constant for the correlation equation determined by Beggs and Robinson (1975);

$R S \quad$ is the solution gas-oil ratio, in standard cubic feet per stock tank barrel (Scf/STB);

100 is a constant for the correlation equation determined by Beggs and Robinson (1975);

0.515 is a curve-fitting exponent determined by Beggs and Robinson (1975);

$B \quad$ is an exponent determined by the value of the solution gas-oil ratio (Beggs and Robinson, 1975);

5.44 is a constant for the correlation equation determined by Beggs and Robinson (1975);

150 is a constant for the correlation equation determined by Beggs and Robinson (1975); and

0.338 is a curve-fitting exponent determined by Beggs and Robinson (1975).

$\mathrm{CO}_{2}$ viscosity $\left(\mathrm{VCO}_{2}\right)$ is based on two-dimensional linear interpolations of $\mathrm{CO}_{2}$ viscosity data associated with specific reservoir temperature and reservoir pressure data as presented in U.S. Department of Energy and Ministry of Energy and Mines of the Republic of Venezuela (1986). 
$\mathrm{CO}_{2}$ compressibility factor $\left(\mathrm{ZCO}_{2}\right)$ is based on two-dimensional linear interpolations of $\mathrm{CO}_{2}$ compressibility factor data associated with specific reservoir temperature and pressure data, as presented in U.S. Department of Energy and Ministry of Energy and Mines of the Republic of Venezuela (1986).

Water viscosity $(V W A T)$ is calculated based on the Van Wingen correlation (American Petroleum Institute, 1950) with equation 34:

$$
V W A T=\exp \left(1.003-0.01479 \times \text { Tres }+0.00001982 \times \text { Tres }^{2}\right)
$$

where

VWAT is the water viscosity, in centipoise (cP);

1.003 is a constant value obtained from curve fitting by Van Wingen (American Petroleum Institute, 1950);

0.01479 is a constant value obtained from curve fitting by Van Wingen (American Petroleum Institute, 1950);

Tres is the reservoir temperature, in degrees Fahrenheit $\left({ }^{\circ} \mathrm{F}\right)$; and

0.00001982 is a constant value obtained from curve fitting by Van Wingen (American Petroleum Institute, 1950).

$\mathrm{CO}_{2}$ formation volume factor $\left(\mathrm{BCO}_{2}\right)$ is calculated using the dimensionless $\mathrm{CO}_{2}$ compressibility factor $(Z$ factor $)$ (Towler, 2006) by equation 35 :

$$
B_{\mathrm{CO} 2}=(0.00503676) \times\left(Z_{\mathrm{CO} 2} \times \text { Tres }+460\right) / P R E S I N
$$

where

$\begin{aligned} B_{\mathrm{CO} 2} & \text { is the } \mathrm{CO}_{2} \text { formation volume factor, in decimal format; } \\ 0.00503676 & \text { is a conversion factor for reservoir barrels per standard cubic foot }(\mathrm{Scf}) ; \\ Z_{\mathrm{CO} 2} & \text { is the } \mathrm{CO}_{2} \text { compressibility factor, dimensionless; } \\ \text { Tres } & \text { is the reservoir temperature, in degrees Fahrenheit }\left({ }^{\circ} \mathrm{F}\right) ; \\ 460 & \text { is the conversion factor for degrees Rankine }\left({ }^{\circ} \mathrm{R}\right) \text {; and } \\ \text { PRESIN } & \text { is the initial reservoir pressure, in pound-force per square inch absolute (psia). }\end{aligned}$

Pseudo-Dykstra-Parsons coefficient $(V D P)$ is computed from the calculated waterflood sweep efficiency and mobility ratio for each reservoir in the CRD database. The procedure was used for the National Petroleum Council's (NPC) 1984 study of enhanced oil recovery and followed a procedure by Robl and others (1986) and Hirasaki and others (1989). The data for the relationships between $V D P$, pseudo-volumetric sweep efficiency, and mobility ratios are presented in graphical form in Hirasaki and others (1984) and Willhite (1986). The graphical data were transferred into tabular data and interpolated with a two-dimensional function. When a $V D P$ could be calculated, and if the value was between 0.1 and 0.5 , it was set equal to 0.5 . Values of the calculated $V D P$ that exceeded 0.98 were interpreted to be the result of inconsistent reservoir or production data, or data outside of the range for the $V D P$ calculation, and were set to a default value of 0.72 as suggested by Hirasaki and others (1984). For some reservoirs having insufficient data, the $V D P$ value is set equal to 0 , and the reservoir is no longer considered a miscible candidate.

Pseudo-volumetric sweep efficiency $\left(E V_{l}\right)$ is defined as the ratio between the volume of oil contacted by the displacing fluid and the volume of original oil in place (Hirasaki and others, 1984; Lake, 1989) and is calculated using equation 36 :

$$
E V_{I}=\frac{E R+(B O I / B O C)-1.0}{(B O I / B O C)(1-S O R W / S O I)}
$$

where

$\begin{aligned} E V_{I} & \text { is the pseudo-volumetric sweep efficiency, in decimal format; } \\ E R & \text { is the recovery factor after waterflood, in decimal format, and is estimated by the NRG known oil } \\ & \text { recovery }\left(K R_{\text {oil }}\right) \text { divided by the original oil in place }(O O I P) ; \\ B O I & \text { is the initial oil formation volume factor, in decimal format; } \\ B O C & \text { is the current oil formation factor, in decimal format; } \\ S O R W & \text { is the residual oil saturation after waterflood, in decimal format; and } \\ S O I & \text { is the initial oil saturation, in decimal format. }\end{aligned}$

For clastic reservoirs, the value of the residual oil saturation after waterflood (SORW) was set equal to 0.25 (National Petroleum Council, 1984). The original SORW value for carbonate reservoirs found in National Petroleum Council (1984) was later revised to 0.305 (D. Remson, U.S. Department of Energy, written commun., 2015). The value 0.305 is used in the CRD for carbonate reservoirs and the value 0.25 is used in the CRD for clastic reservoirs.

The development of $E V_{l}$ (equation 36) is only used as an internal variable to calculate the pseudo-Dykstra-Parsons coefficient $(V D P)$. A second equation (equation 37), calculates the pseudo-volumetric sweep efficiency $\left(E V_{2}\right)$ used in assessing the technically recoverable hydrocarbons that are producible using $\mathrm{CO}_{2}$ enhanced oil recovery processes. $E V$ is calculated in equation 37 as: 
where

$$
E V_{2}=\frac{K R_{\text {oil }} \times 1,000}{7,758 \times \text { Area } \times \text { NetPay } \times \text { Por } \times\left[\frac{S O I}{B O I}-\frac{S O R W}{B O C}\right]}
$$

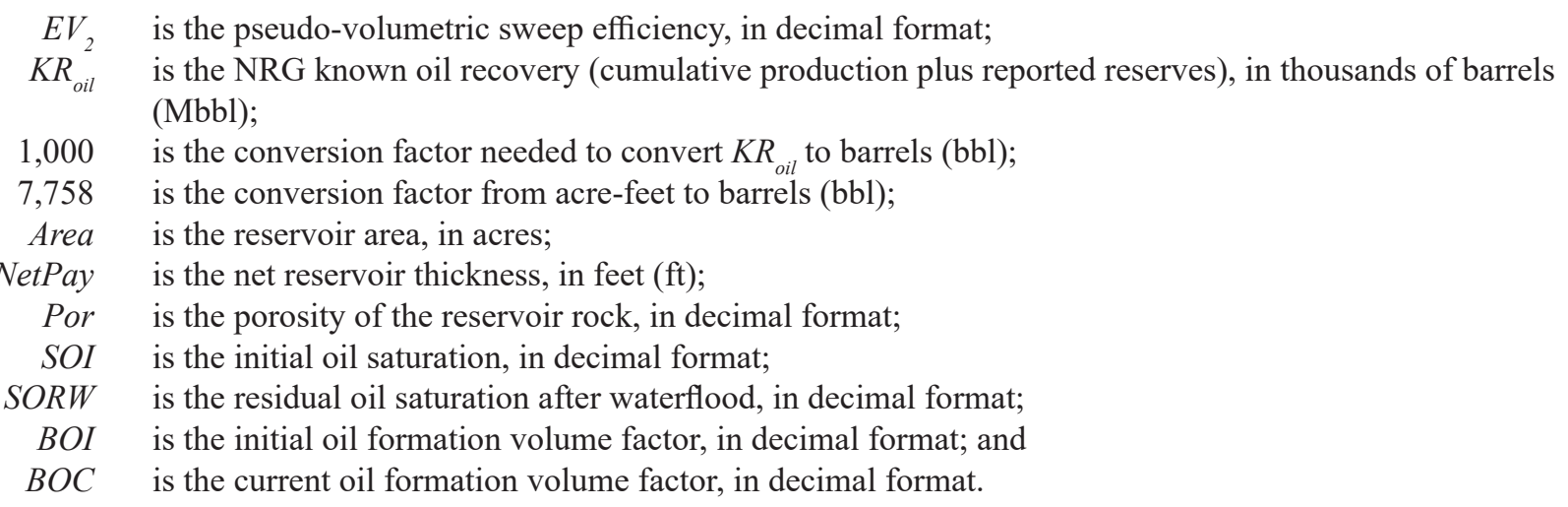

\section{Gas Reservoir and Fluid Properties}

Current reservoir pressure (PRESC) for gas reservoirs is calculated the same as for oil reservoirs (equation 20).

Current gas saturation $(S G C)$ is calculated using equation 38 , when the initial gas formation volume factor (BGI) and the original gas in place $(O G I P)$ are greater than zero:

$$
S G C=\frac{O G I P-\text { cumprod }}{O G I P} \times S G I \times \frac{B G C}{B G I}
$$

where

$\begin{aligned} S G C & \text { is the current gas saturation, in decimal format; } \\ \text { OGIP } & \text { is the original gas in place, in billions of cubic feet (Bcf); } \\ \text { cumprod } & \text { is the cumulative gas production, in billions of cubic feet (Bcf); } \\ S G I & \text { is the initial gas saturation, in decimal format; } \\ B G C & \text { is the current gas formation volume factor, in decimal format; and } \\ B G I & \text { is the initial gas formation volume factor, in decimal format. }\end{aligned}$

Original gas in place $(O G I P)$ is calculated in equation 39 as:

$$
O G I P=G I P V O L \times \text { area }
$$

where

OGIP is the original gas in place, in standard cubic feet (Scf);

GIPVOL is the original gas-in-place volume per unit area, in standard cubic feet per acre (Scf/acre); and

area is the reservoir area, in acres.

Original gas-in-place volume per reservoir area $(G I P V O L)$ for conventional reservoirs is calculated in equation 40 as:

$$
G I P V O L=\frac{43,560 \times \text { Por } \times \text { NetPay } \times S G I}{0.02829 \times Z_{i} \times(\text { Tres }+460)} \times P R E S I N
$$

where

GIPVOL is the original gas-in-place volume per reservoir area, in standard cubic feet per acre (Scf/acre);

43,560 is the conversion factor from acre-feet to cubic feet $\left(\mathrm{ft}^{3}\right)$;

Por is the porosity of reservoir rock, in decimal format;

NetPay is the net reservoir thickness, in feet $(\mathrm{ft})$;

SGI is the initial gas saturation, in decimal format;

0.02829 is the conversion factor for the compressibility of gas at standard conditions $\left(14.7 \mathrm{psia}\right.$ and $\left.60^{\circ} \mathrm{F}\right)$; 
$Z_{i} \quad$ is the initial gas compressibility factor;

460 is the conversion factor for degrees Rankine $\left({ }^{\circ} \mathrm{R}\right)$;

Tres is the reservoir temperature, in degrees Fahrenheit $\left({ }^{\circ} \mathrm{F}\right)$; and

PRESIN is the initial reservoir pressure, in pound-force per square inch absolute (psia).

Initial gas formation volume factor $(B G I)$ is calculated in equation 41 as:

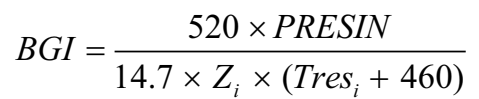

where

$B G I$ is the initial gas formation volume factor, in decimal format;

520 is the coefficient for the current gas formation volume factor;

PRESIN is the initial reservoir pressure, in pound-force per square inch absolute (psia);

14.7 is the standard atmospheric pressure, in pound-force per square inch (psi);

$Z_{i} \quad$ is the initial gas compressibility factor;

Tres $_{i} \quad$ is the initial reservoir temperature, in degrees Fahrenheit $\left({ }^{\circ} \mathrm{F}\right)$; and

460 is the conversion factor for degrees Rankine $\left({ }^{\circ} \mathrm{R}\right)$.

Current gas formation volume factor $(B G C)$ is calculated in equation 42 as:

$$
B G C=\frac{520 \times \text { PRESC }^{-7.7 \times Z_{c} \times\left(\text { Tres }_{c}+460\right)}}{14}
$$

where

$B G C$ is the current gas formation volume factor, in decimal format;

520 is the coefficient for the current gas formation volume factor;

PRESC is the current reservoir pressure, in pound-force per square inch absolute (psia);

14.7 is the standard atmospheric pressure, in pound-force per square inch (psi);

$Z_{c} \quad$ is the current gas compressibility factor;

Tres $_{c} \quad$ is the current reservoir temperature, in degrees Fahrenheit $\left({ }^{\circ} \mathrm{F}\right)$; and

460 is the conversion factor for degrees Rankine $\left({ }^{\circ} \mathrm{R}\right)$.

Generally, $Z_{c}$ is assumed to be equal to the initial gas compressibility factor $\left(Z_{i}\right)$.

Initial pressure for gas reservoirs (PRESIN) is calculated with the same procedure as for the oil reservoir initial pressure in the absence of values in the NRG database.

Current pressure for gas reservoirs (PRESC) is calculated using equation 43, where $Z_{c}$ is assumed to be equal to $Z_{i}$ :

$$
\frac{\text { PRESC }}{Z_{c}}=\frac{\text { PRESIN }}{Z_{i}} \times\left(1-\frac{\text { cumprod }}{\text { OGIP }}\right)
$$

where

PRESC is the current reservoir pressure, in pound-force per square inch absolute (psia);

PRESIN is the initial reservoir pressure, in pound-force per square inch absolute (psia);

cumprod is the cumulative gas production, in billions of cubic feet (Bcf);

$Z_{c} \quad$ is the current gas compressibility factor;

$Z_{i} \quad$ is the initial gas compressibility factor; and

$O G I P$ is the original gas in place, in billions of cubic feet (Bcf).

Initial gas compressibility factor $\left(Z_{j}\right)$ is calculated as a function of the specific gravity of gas, its content of carbon dioxide $\left(\mathrm{CO}_{2}\right)$ and hydrogen sulfide $\left(\mathrm{H}_{2} \mathrm{~S}\right)$, reservoir pressure, and reservoir temperature, and is based on correlations described in Standing and Katz (1942) and Wichert and Aziz (1971).

Specific gravity of the gas $(S G G)$ is provided by the NRG database, or if the value is not provided in the NRG database, it is estimated by the play or province average. If average data are not available the default value is 0.8 .

Reservoir water influx volume (WATIN) is calculated by equation 44 as:

$$
\text { WATIN }=\text { cumprod } \times B G C-O G I P \times(B G C-B G I)
$$


where

WATIN is the reservoir water influx volume, in billions of cubic feet (Bcf);

cumprod is the cumulative gas production, in billions of cubic feet (Bcf);

$B G C$ is the current gas formation volume factor, in decimal format;

OGIP is the original gas in place, in billions of cubic feet (Bcf); and

$B G I$ is the initial gas formation volume factor, in decimal format.

Estimated ultimate recovery $(E U R)$ for gas reservoirs is calculated with equation 45 (in the equation the contaminant gases, $\mathrm{CO}_{2}, \mathrm{~N}_{2}$, and $\mathrm{H}_{2} \mathrm{~S}$ are in molecular percent of the total gas in the reservoir):

$$
E U R=\frac{K R_{\text {gas }}}{\left(100-\mathrm{CO}_{2}-\mathrm{N}_{2}-\mathrm{H}_{2} \mathrm{~S}\right)}+1.302 \times K R_{N G L}
$$

where

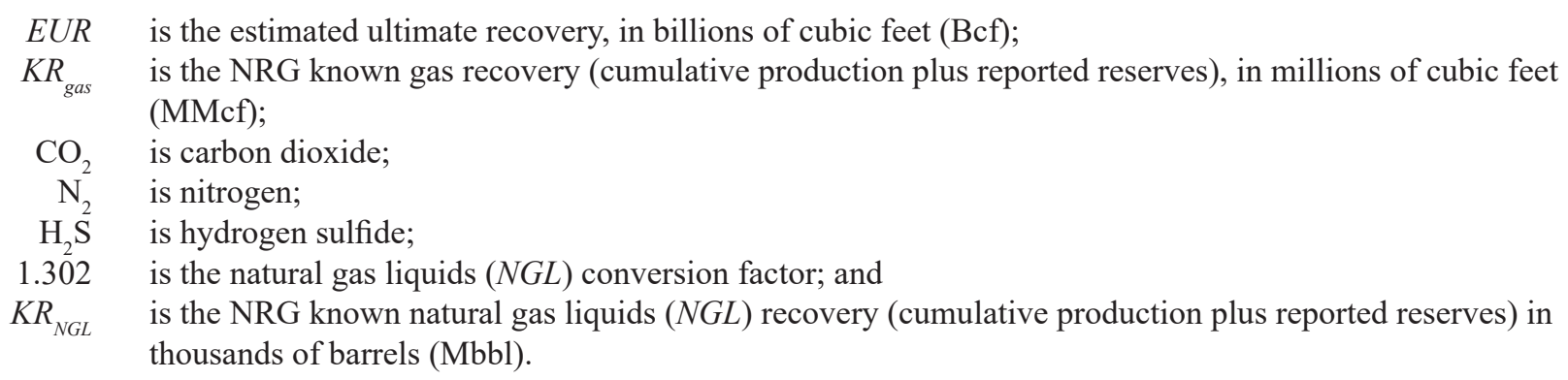

The EUR is the raw gas volume and includes the gas contaminants $\mathrm{CO}_{2}, \mathrm{~N}_{2}$, and $\mathrm{H}_{2} \mathrm{~S}$. The $K R_{\text {gas }}$ and $K R_{N G L}$ data are in the form of marketable gas (cumulative production plus reported reserves) and natural gas liquids, as reported in the NRG database at the end of 2010. All $K R_{g a s}$ and $K R_{N G L}$ data used as inputs to the equations are from NRG database. The natural gas liquids $(N G L)$ conversion factor converts barrels (bbl) to thousands of cubic feet (Mcf) using volume, and it is used to convert NGL to dry gas using British thermal units (Btu). These conversions are derived using equation 46:

where

$$
1.302=\frac{5.614}{\left(\frac{5.418}{1.250}\right)}
$$

1.302 is the natural gas liquids $(N G L)$ conversion factor;

5.614 is the assumed cubic feet of gas per barrel of oil;

5.418 is million British thermal units per barrel of plant condensate (U.S. Energy Information Administration, 2012); and

1.250 is the assumed average British thermal units per cubic foot $\left(\mathrm{Btu} / \mathrm{ft}^{3}\right)$ of liquids-rich dry gas (Braziel, 2012).

Gas reservoir recovery factor $(R E C Y)$ is calculated using equation 47 as:

$$
R E C Y=\frac{E U R}{A C P R O D \times G I P V O L}
$$

where

RECY is the gas reservoir recovery factor, in decimal format;

$E U R$ is the estimated ultimate recovery, in standard cubic feet (Scf);

$A C P R O D$ is the producing area, in acres; and

GIPVOL is the original gas-in-place volume per unit area, in standard cubic feet per acre (Scf/acre). 


\section{Summary}

The Comprehensive Resource Database (CRD) was developed to support hydrocarbon assessments prepared by the U.S. Geological Survey (USGS). The CRD contains the location, key petrophysical properties, production, and well counts for the major oil and gas reservoirs in the onshore and State waters areas of the conterminous United States and Alaska. The data within the CRD cannot be released to the public because it includes proprietary field and reservoir petrophysical property data from the Nehring Associates (2012) "Significant Oil and Gas Fields of the United States Database" and proprietary production and drilling data from "Petroleum Information Data Model Relational U.S. Well Data" prepared by IHS Inc. (2012). This report provides a description of (1) the CRD computer program and its methodology, (2) a list of the key data sources used in its development, (3) a description of the steps and routines used to prepare the CRD, (4) the screening criteria for miscible or immiscible $\mathrm{CO}_{2}$ flooding applied to the CRD, (5) the database outputs, and (6) documentation of the computational procedures that were applied. The equations used in the calculations, a list of the input and output reservoir property data and variables, the computer code, and the CRD are on file at the USGS Eastern Energy Resources Science Center located in Reston, Va.

\section{Acknowledgments}

The authors acknowledge the helpful reviews of this report by Troy Cook of the U.S. Energy Information Administration, and James Coleman and Timothy Klett of the U.S. Geological Survey. Additional comments on the manuscript by Hossein Jahediesfanjani and Jacqueline Roueche (Lynxnet contractors to the U.S. Geological Survey) are appreciated.

\section{References Cited}

American Petroleum Institute, 1950, Secondary recovery of oil in the United States (2d ed.): Division of Production, New York, American Petroleum Institute, 838 p.

Andrei, Maria, De Simoni, Michela, Delbianco, Alberto, Cazzani, Piero, and Zanibelli, Laura, 2010, Enhanced oil recovery with $\mathrm{CO}_{2}$ capture and sequestration: 2010 World Energy Council, Montreal, Canada, September 12-16, 2010, 20 p., accessed February 13, 2017, at http:/www.indiaenergycongress.in/montreal/library/ pdf/231.pdf.
Attanasi, E.D., 1998, Economics and the 1995 National assessment of United States oil and gas resources: U.S. Geological Survey Circular 1145, 35 p., accessed May 8, 2015, at https://pubs.er.usgs.gov/publication/ cir1145.

Beeman, W.R., Obuch, R.C., and Brewton, J.D., comps., 1996, Digital map data, text, and graphical images in support of the 1995 National assessment of United States oil and gas resources: U.S. Geological Survey Digital Data Series DDS-35, 1 CD-ROM.

Beggs, H.D., and Robinson, J.R, 1975, Estimating the viscosity of crude oil systems: Journal of Petroleum Technology, v. 27, no. 9, p. 1,140-1,141. [Also available at https://www.onepetro.org/journal-paper/SPE-5434-PA.]

Braziel, Rusty, 2012, How rich is rich?-How BTU content and GPM determine NGL quantities (Part II): RBN Energy LLC, accessed May 15, 2013, at https://rbnenergy.com/ how-rich-is-rich-how-btu-content-and-gpm-determine-nglquantities-part-II.

British Columbia Oil and Gas Commission, 2014, Policy for determining primary product of oil or gas: British Colombia Oil and Gas Commission, Reservoir Engineering Department, 1 p., accessed June 11, 2015, at https://www.bcogc.ca/policy-determining-primary-productoil-or-gas.

Clark, C.E., and Veil, J.A., 2009, Produced water volumes and management practices in the United States: Argonne National Laboratory, Environmental Science Division report ANL/EVS/R-09/1, 60 p. [Also available at http://www.ipd. anl.gov/anlpubs/2009/07/64622.pdf.] [Prepared for the U.S. Department of Energy, Office of Fossil Energy, National Energy Technology Laboratory, under contract DE-AC0206CH11357.]

Gautier, D.L., Dolton, G.L., Takahashi, K.I., and Varnes, K.L., eds., 1996, 1995 National assessment of United States oil and gas resources; Results, methodology, and supporting data (release 2): U.S. Geological Survey Digital Data Series DDS-30, 1 CD-ROM.

Henline, W.D., Young, M.A., and Nguyen, J.T., 1985, Feasibility study to modify the DOE steamflood and $\mathrm{CO}_{2}$ (miscible) flood predictive models respectively to include light oil steamflooding and immiscible gas drive: U.S. Department of Energy National Institute for Petroleum and Energy Research Topical Report NIPER-54, Cooperative Agreement DE-FC01-83FE60149, 13 p., accessed September 23, 2014, at http:/www.netl.doe.gov/KMD/cds/ disk22/G-CO2\%20\&\%20Gas\%20Injection/NIPER54.pdf. 
Hirasaki, G.J., Morra, Frank, and Willhite, G.P., 1984, Estimation of reservoir heterogeneity from waterflood performance: Society of Petroleum Engineers, SPE-13415-MS, 10 p., accessed February 12, 2015, at https://www.onepetro.org/general/SPE-13415-MS.

Hirasaki, G.J., Stewart, W.C., Elkins, L.E., and Willhite, G.P., 1989, Reply to discussion of the 1984 National Petroleum Council studies on EOR: Journal of Petroleum Technology, v. 41 , no. 11 , p. $1,218-1,222$.

Hite, D.M., 2006, Use of $\mathrm{CO}_{2}$ in EOR background and potential application to Cook Inlet oil reservoirs, South Central Alaska Energy Forum, Anchorage, Alaska, September 20-21, 2006: U.S. Department of Energy [Artic Energy Office], 13 p., accessed September 23, 2014, at http://doa.alaska.gov/ogc/reports-studies/EnergyForum/06 ppt_pdfs/27_hite.pdf.

Holm, L.W., and Josendal, V.A., 1974, Mechanisms of oil displacement by carbon dioxide: Journal of Petroleum Technology, v. 26, no. 12, p. 1,427-1,436. [Also available at https://www.onepetro.org/journal-paper/SPE-4736-PA.]

IHS Inc., 2012, PIDM [Petroleum Information Data Model] relational U.S. well data [data current as of December 23, 2012]: Englewood, Colo., IHS Inc., database.

INTEK Inc. and Resource Consultants, Inc., 2006, Onshore lower 48 oil and gas supply submodule; Component design report: U.S. Department of Energy, Energy Information Administration, Office of Integrated Analysis and Forecasting, 64 p., accessed October 22, 2015, at http://www.eia.gov/forecasts/documentation/workshops/pdf/ ologss_cdr.pdf. [Prepared under prime contract DE-AM0104EI42006 and DOE Task Orders DE-AT01-05EI40220. A000 and DE-AT01-06EI40242.A000.]

Klett, T.R., Schmoker, J.W., Charpentier, R.R., Ahlbrandt, T.S., and Ulmishek, G.F., 2005, Glossary, chap. 25 of U.S. Geological Survey Southwestern Wyoming Province Assessment Team, comp., Petroleum systems and geologic assessment of oil and gas in the Southwestern Wyoming Province, Wyoming, Colorado, and Utah: U.S. Geological Survey Digital Data Series DDS-69-D, 3 p., CD-ROM. [Also available at http://pubs.usgs.gov/dds/dds-069/dds069-d/.]

Koottungal, Leena, 2012, 2012 worldwide EOR survey: Oil and Gas Journal, v. 110, no. 4 (April 2), p. 57-69, accessed January 15, 2013, at http://www.ogj.com/articles/print/ vol-110/issue-4/general-interest/special-report-eor-heavyoil-survey/2012-worldwide-eor-survey.html.

Koottungal, Leena, 2014, 2014 worldwide EOR survey: Oil and Gas Journal, v. 112, no. 4 (April 7), p. 78-97, accessed June 11, 2015, at http://www.ogj.com/articles/ print/volume-112/issue-4/special-report-eor-heavy-oilsurvey/2014-worldwide-eor-survey.html.
Lake, L.W., 1989, Enhanced oil recovery: Englewood Cliffs, New Jersey, Prentice-Hall, Inc., 550 p.

Lyons, W.C., ed., 1996, Standard handbook of petroleum and natural gas engineering, volume 2: Houston, Texas, Gulf Publishing Company, 1,090 p.

Mungan, Necmettin, 1981, Carbon dioxide flooding; Fundamentals: Journal of Canadian Petroleum Technology, v. 20. no. 1, p. 87-92, accessed July 17, 2013, at http://dx.doi.org/10.2118/81-01-03.

National Petroleum Council (NPC), 1984, Enhanced oil recovery: Washington D.C., National Petroleum Council, variously paged [285 p.], accessed September 9, 2014, at http://www.npc.org/reports/rby.html.

Nehring Associates, 2008, The field cross reference table [data current as of December 2006]: Colorado Springs, Colo., Nehring Associates, Inc.

Nehring Associates, 2012, Significant oil and gas fields of the United States database [data current as of December 2010]: Colorado Springs, Colo., Nehring Associates, Inc.

Robl, F.W., Emanuel, A.S., and Van Meter, O.E., Jr, 1986, The 1984 National Petroleum Council estimate of potential EOR for miscible processes: Journal of Petroleum Technology, v. 38 , no. 8 , p. $875-882$.

Satter, Abdus, Iqbal, G.M., and Buchwalter, J.L., 2008, Practical enhanced reservoir engineering: Tulsa, Oklahoma, PennWell Corporation, $688 \mathrm{p}$.

Standing, M.B., 1948, A pressure-volume-temperature correlation for mixtures of California oils and gases, in Drilling and Production Practice, 1947: New York, American Petroleum Institute and Society of Petroleum Engineers, p. 275-287, accessed May 11, 2015, at https://www.onepetro.org/conference-paper/API-47-275.

Standing, M.B., and Katz, D.L., 1942, Density of natural gases: Transactions of the American Institute of Mining Engineers (AIME), Society of Petroleum Engineers, SPE-942140-G, 10 p. [Also available at https://doi. org/10.2118/942140-G.]

Taber, J.J., Martin, F.D., and Seright, R.S., 1997, EOR screening criteria revisited, part 2; Applications and impact of oil prices: Society of Petroleum Engineering, Reservoir Engineering, v. 12. no. 3, p. 199-205. [Also available at https://www.onepetro.org/journal-paper/SPE-39234-PA.]

Towler, B.F., 2006, Gas properties, chap. 5 of Fanchi, J.R., ed., General engineering, petroleum engineering handbook, volume 1: Richardson, Tex., Society of Petroleum Engineers, $864 \mathrm{p}$. 
U.S. Department of Energy, and Ministry of Energy and Mines of the Republic of Venezuela, 1986, Supporting technology for enhanced oil recovery; $\mathrm{CO}_{2}$ miscible flood predictive model: U.S. Department of Energy and Ministry of Energy and Mines of the Republic of Venezuela, DOE Fossil Energy Report III-6, variously paged [466 p.], accessed May 11, 2015, at http://www.netl.doe.gov/kmd/ cds/disk22/B-Reservoir\%20Screening_\%20Simulation/ CO2\%20Miscible\%20Flood\%20Predictive\%20Model $\% 20$ Folder/BC86_12_SP.pdf.

U.S. Energy Information Administration, 2012, Annual Energy Review 2011: U.S. Energy Information Administration [Report] DOE/EIA-0384(2011), 370 p., accessed June 8, 2015, at http://www.eia.gov/totalenergy/data/annual/pdf/aer.pdf.

U.S. Energy Information Administration, 2013a, Crude oil production; Period-unit—Annual-thousand barrels per day: U.S. Energy Information Administration web page, accessed February 28, 2013, at http://www.eia.gov/dnav/ pet/pet_crd_crpdn_adc_mbblpd_a.htm.

U.S. Energy Information Administration, 2013b, Natural gas gross withdrawals and production (volumes in million cubic feet); Data series, gross withdrawals [and] Periodunit—Annual-million cubic feet: U.S. Energy Information Administration web page, accessed February 28, 2013, at http://www.eia.gov/dnav/ng/ng_prod_sum_a_EPG0_FGW_ mmcf_a.htm.

U.S. Geological Survey Energy Resources Program Geochemistry Database, 2014, Energy Geochemistry Database: U.S. Geological Survey Energy Resources Program web page, accessed December, 2016, at https://energy.usgs.gov/GeochemistryGeophysics/GeochemistryLaboratories/GeochemistryLaboratories-GeochemistryDatabase.aspx\#4413378download-data.

U.S. Geological Survey Geologic Carbon Dioxide Storage Resources Assessment Team, 2013, National assessment of geologic carbon dioxide storage resources-Data (ver. 1.1, September 2013): U.S. Geological Survey Data Series 774, 13 p., plus 2 appendixes and 2 large tables in separate files, accessed October 15, 2014, at http://pubs.usgs.gov/ds/774/. [Supersedes ver. 1.0 released June 26, 2013.]

Vasquez, M.E., and Beggs, H.D., 1980, Correlations for fluid physical property predictions, SPE-6719-PA: Journal of Petroleum Technology, v. 32, no. 6, p. 968-970. [Also available at https://www.onepetro.org/journal-paper/SPE6719-PA.]

Wichert, Edward, and Aziz, Khalid, 1971, Compressibility factor of sour natural gases: The Canadian Journal of Chemical Engineering, v. 49, no. 2, p. 267-273. [Also available at https://doi.org/10.1002/cjce.5450490216.]

Willhite, G.P., 1986, Waterflooding: Society of Petroleum Engineers Textbook Series, v. 3, 326 p. 

Manuscript approved on May 31, 2017

For additional information regarding this publication, contact:

Director, USGS Energy Resources Program

12201 Sunrise Valley Drive, MS 913

Reston, VA 20192

Or visit USGS Energy Resources Program at http://energy.usgs. gov/Generallnfo/AbouttheEnergyProgram.aspx.

Prepared by the USGS Science Publishing Network Reston Publishing Service Center

Edited by David A. Shields

Layout by Cathy Y. Knutson and Jeannette M. Foltz 
产

望

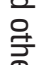

产

ISSN 2328-7055 (online) 